\title{
Mit livslange arbejde med sønderjysk historie
}

\author{
af H.V. GREGERSEN
}

Den 3. juli 2000 fyldte dr.phil. H.V. Gregersen, Haderslev, 80 år. Fødselaren kan se tilbage på et imponerende forfatterskab inden for sønderjysk historie. Med sin letløbende og fængende pen har han evnet at få de mange i tale. På mange punkter har han øget vor viden og bragt forskningen videre. Til Historisk Samfund for Sønderjyllands publikationsrækker har han været bidragyder, flittig som få.

Nedenstående giver $\mathrm{H}$.V. Gregersen et rids af de mange års beskæftigelse med hjemstavnens historie. Fra Historisk Samfund skal der lyde en tak til forfatteren for utrætteligt arbejde - til manges glæde og oplysning og til gavn for videnskaben.

"Nulla dies sine linea " har man kunnet sige om mit arbejde med min sønderjyske hjemstavnshistorie gennem en menneskealder. I årenes løb er det blevet til godt en snes bøger og mere end 400 artikler og afhandlinger. Hele dette arbejde har været min fritidsbeskæftigelse, en hobby, om man vil. Det har været lysten, der har drevet værket, dette at indsamle et materiale, trykt og utrykt, og udmønte det i en skriftlig fremstilling.

Det hænder i ny og næ for mig (født 1920), at jeg spekulerer på, om min årelange beskæftigelse med min sønderjyske hjemstavns historie nu også har kunnet bidrage med øget viden herom, og det er denne overvejelse, der nu på mine gamle dage får mig til at udarbejde efterstående oversigt over mit historiske forfatterskab. Anledningen hertil er modtagelsen af Christian Paulsen-prisen den 10. januar 1998 i Billedsalen på »Folkehjem « i Aabenraa. I sin egenskab af formand for priskomiteen begrundede Lars N. Henningsen i sin "laudatio" overrækkelsen af denne pris med, at jeg "har ydet et afgørende bidrag til forståelse af mange sider af Sønderjyllands historie«, og det blev aftalt, at jeg skulde fortælle den tilstedeværende forsamling lidt om mit livslange arbejde med min hjemstavns historie. I sit brev et par dage efter festen skrev Lars N. Henningsen, at mit indlæg kunde blive trykt $\mathrm{i}$ "Sønderjyske Årbøger«, også med 


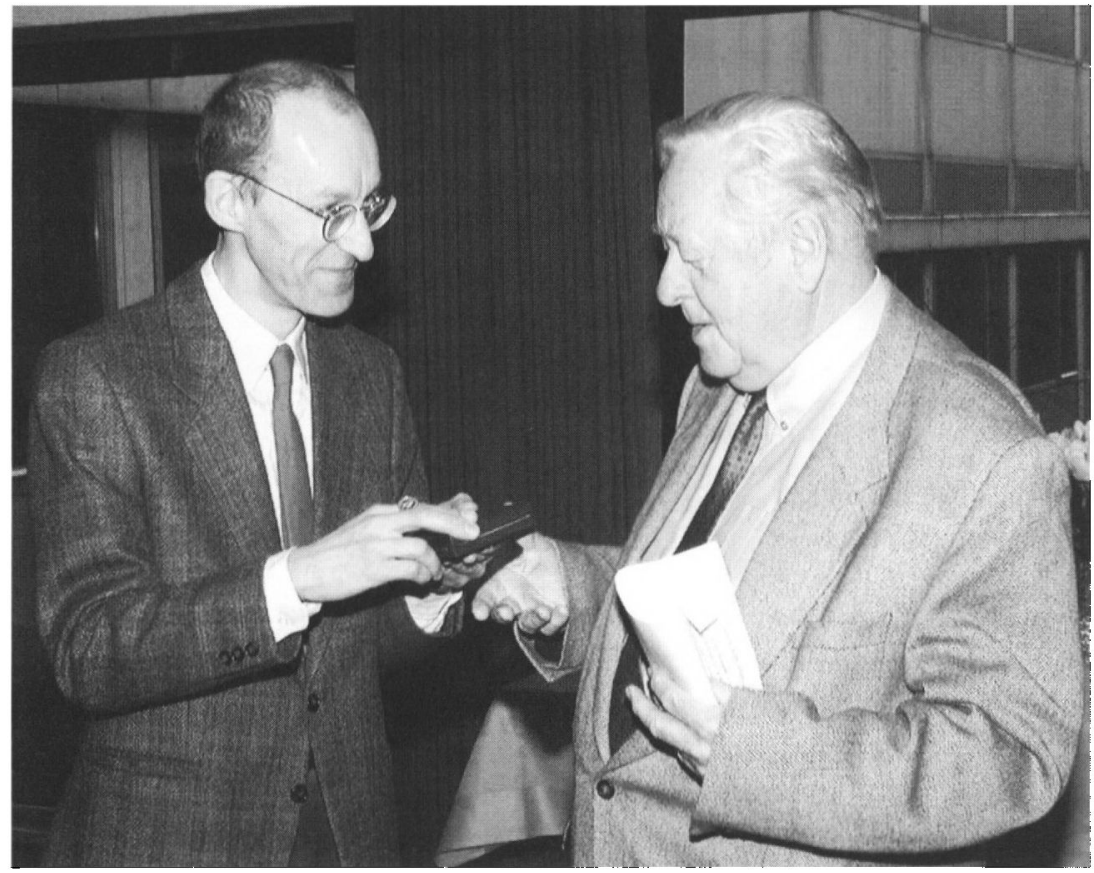

H. V. Gregersen (t.h.) modtager Christian Paulsen-prisen 10. januar 1998. Foto: Mikkel Mauter, Flensborg Avis.

evt. udvidelser eller ændringer. Resultatet af denne opfordring er nu blevet til de følgende sider.

Inden jeg slutter min indledning, vil jeg gerne fremhæve, at min beskæftigelse som udøvende historiker har betydet, at jeg har været i stand til at se et historisk forløb helt anderledes indefra, end kendskabet hertil ellers vilde have været. Jeg har følt, at det har givet mig en faglig styrke, som jeg har kunnet trække på i undervisningssituationerne, og det har nok ført til, at jeg i årene 1972 til 1986 havde hvervet som "central studielektor" $i$ faget historie $i$ Undervisningsministeriets seminariedirektorat, hvortil kom, at jeg i 1970 uansøgt blev beskikket som censor i faget ved universiteterne i Kobenhavn, Århus og Odense. Mit daglige virke som underviser og mine mange foredrag (fortrinsvis rundt omkring i den sønderjyske landsdel) har tvunget mig til at fremlægge det historiske stof på en så vidt gørlig overskuelig og klar måde. Om det så altid er lykkedes for mig, vil andre bedre kunne bedømme. 


\section{Salthandel ${ }^{1}$}

Min første afhandling går tilbage til »Sønderjysk Månedsskrifts« majnummer 1947, og dens emne var salthandel.

Min beskæftigelse med saltets historie skyldtes en ren tilfældighed, idet jeg i Rigsarkivet dumpede ned i nogle akter vedr. den "Lüneburgske saltoktroi «, og dem blev jeg straks fascineret af. Pakkens indhold gav mig ikke blot et indtryk af saltets betydning som vigtigste vare $\mathrm{i}$ ældre tiders handelshistorie, men også af alle de foranstaltninger, der netop af denne grund blev truffet for at bremse enhver form for smugleri. Det var de indviklede jurisdiktionelle tilstande i de såkaldt blandede distrikter i det vestlige Slesvig, som den pågældende pakke handlede om, og som viste, at forholdene her var som skabt til smugleri.

Under arbejdet med min afhandling blev jeg mere og mere klar over, at det var et emne, der i dansk historieskrivning på det nærmeste var overset. Salt har jo af gode grunde ikke efterladt sig arkæologiske spor som andre handelsartikler. Den manglende interesse for dette emne er så meget des mere ejendommelig, eftersom alle nordiske lande var afhængige af tilførsel af salt. Allerede $i$ vikingetiden rettedes togter mod udvindings-stederne for havsalt ved bugten Baie syd for Loire-mundingen, og i middelalderen førtes salt fra Lüneburg via Lübeck til sildemarkedet ved Øresund. Efterspørgslen efter salt indgik derfor i skiftende regeringers politik indtil ca. 1800, da udvindingen af stensalt medførte, at salt ikke mere var en mangelvare.

Det var alt dette, der optog mit sind, og da jeg af Undervisningsministeriet fik et legat og embedsorlov, fandt jeg ved studier i London og Lüneburg og i mere nærliggende arkiver stof til bogen »Den Lüneburgske Saltoktroi«. Den kom i 1962 og blev af flere anset for at være et forsøg på at skrive en disputats, hvilket slet ikke var hensigten. Det var alene interessen, der førte mig ud på disse vidder.

Men jeg fandt det fortsat højst ejendommeligt, at der ikke på dansk fandtes en sammenfattende skildring af saltets betydning i ældre tiders handelsliv, og jeg forsøgte da at rette op herpå med en afhandling $\mathrm{i}$ "Kulturgeografi«. Det var A. Krarup Mogensen, som jeg lærte at kende $i$ forbindelse med censorvirksomhed, der skaffede mig adgang til dette tidsskrift.

I min bog "Slesvig og Holsten indtil $1830 \ll$ har jeg et afsnit, som jeg har kaldt »Danmarks tærskel ud mod Europa«. Jeg skrev dette afsnit, 
fordi jeg fandt, at det var en forsømmelse, at salt som vigtigste handelsvare almindeligvis bliver forbigået $i$ oversigtsværker. Ud fra det sparsomme kildestof, der er levnet fra vikingetiden, søgte jeg at påvise en saltvej langs med kysten af Nordsøen fra Ejder-mundingen til Baie-de-Bourgneuf syd for Loires udløb i Biscaya-bugten. Jeg spurgte dengang værkets redaktør, Svend Ellehøj, hvad han mente herom. Han svarede blot, at det var mit historikeransvar. Dette ansvar har jeg siden søgt at leve op til i mine forskellige afhandlinger om vikingetiden og i mit bidrag til »Dansk Kulturhistorisk Opslagsværk«.

\section{Urnehoved $^{2}$}

Engang i 1947 arrangerede Peter Kr. Iversen et møde på Landsarkivet i Aabenraa med Hans J. Bertelsen, Jakob Holdt og mig som deltagere. Dette møde blev, som årene gik, til mange, og et nært venskab med de to lærere varede ved til deres død. Deres ærinde i Landsarkivet gjaldt planen om udarbejdelsen af en Bjolderup sogns historie. Det blev et større arbejde, der udkom i to halvbind i årene 1951 og 1956, men dermed var der også skabt en sognehistorie, som efter anmelderes mening dengang ikke havde sin lige i Sønderjylland. Medarbejderne var alle fra Bjolderup sogn eller havde tilknytning til det. P.Kr. Iversen blev min medredaktør som garant for værkets standard og for at hjælpe til med at skaffe penge til udgivelsen.

For historisk interesserede ikke blot i Bjolderup sogn måtte afsnittet om det gamle landsting på Urnehoved helt naturligt påkalde sig størst interesse, idet spørgsmålet om, hvor man skulle søge tingpladsen, allerede var blevet aktuelt efter fremkomsten af ingeniør Vilhelm Marstrands ejendommelige bog "Aabenraa c. 1028-1523 « fra 1933. Ikke mindst gjorde egnens historisk interesserede landmand, Hans Peter Jørgensen fra "Olmersvold « i Uge sogn, sig til talsmand for, at tingpladsen skulde søges på marken "Løgpold«. Han støttede sig til læreren Jes N. Schmidts "antiquarisk-topographiske« afhandling fra 1850 , hvori navnet »Logpold « blev opfattet som en variant af "Lovpold « og dermed stedet, hvor love var blevet vedtaget. Det var baggrunden for, at et nystiftet Urnehoved-selskab med H.P. Jørgensen som formand her fik anlagt en festplads.

Engang i sommeren 1948 tog Karen Margrethe og jeg med rutebilen fra Aabenraa mod Tinglev, og vi stod af ved Petersborg for at vandre resten af vejen mod Tinglev $i$ det smukke vejr, vi havde den dag. Vi 
gik nordpå ad Hærvejen, og det var derefter tanken at fortsætte vestpå ind mod Bolderslev og derfra mod sydvest ad Frisvejen til Lovtrup og videre til Tinglev, hvor min Søster ventede os med en stor kotelet. Men da vi på Hærvejen passerede »Løgpold« med festpladsen, stod Hans Peter Jørgensen der, og vi kom hurtigt ind i en større diskussion. Jeg forsøgte at forklare ham, at når man skriver historie, kan man ikke smutte uden om kendsgerninger. "Logpold" kunde ikke være stedet, hvor Urnetinget var blevet afholdt, men at det da trods dette var udmærket med en festplads, hvor egnens folk kunde mødes ved festlige lejligheder. Men Jørgensen lod sig ikke rokke, og da vi forlod ham, råbte han efter mig: "Dærre mæ æt it, Gregersen! Dærre mæ æt it!!« (I oversættelse: "Fordærv det ikke for mig«, d.v.s. "ødelæg det ikke for mig «). I den grad identificerede han sig med opfattelsen af »Løgpold « som Urnehoved tingplads. Jeg måtte imidlertid stå fast på, at i en historisk fremstilling kan man ikke lave fuskerier.

Når "Løgpold « måtte lades ude af betragtning, skyldes det, at alle sprogkyndige siger, at navnet ikke kan sidestilles med "Lovpold «, således som J. N. Schmidt i sin tid havde ment. I oldtid og tidlig middelalder udgjorde området omkring "Løgpold « herredskellet mellem Rise og Slogs herred og var skovdækket, mens gravhøje tydeligt viser, at Hærvejen oprindelig gik i en bue uden om Urnehoved-banken. Selve navnet »Løgpold « dukker først op i 1837 og kan muligvis opfattes som en spotteglose over et mislykket forsøg $i$ årene 1751-1783 på at etablere en kro på dette sted (Stenbjerg kro). Løg fra kroens urtehave var sammen med nogle murstensrester, hvad der var tilbage på dette sted. Marknavnet »Løgpold « har i så fald ikke klang af hedenold.

J.N. Schmidts »antiquarisk-topographiske« kort fra 1850 viser kun et sted på Urnehoved, hvortil der kan findes arkivalsk dækning for noget specielt, idet han på bankens højeste sted har afsat ordene "Spor af Baldursborgen«. Det jordstykke, der hentydes til, nævnes i en fortegnelse fra 1443 over jord, der hørte til Bjolderup kirke, og det er her anonymt, idet der kun siges, at det ligger "ved Hestehaverne" ("apud Heesthaue«). I samme fortegnelse (eller kirkeinventarium) nævnes et lille jordstykke mere, som der ikke har været plads til på J.N. Schmidts kort. Det hedder herom, at det ligger i »Lyseg«, en del af "skoven i Urne". En anden kilde oplyser, at det lille jordstykke hedder "Noracker ", et navn, der ikke kan sidestilles med "Nørreager" på Bolderslev bymark. Rigsarkivar Svend Aakjær, der var filolog og 
en stor kender af middelalderens bebyggelseshistorie, meddelte mig i sin tid, at der ikke vilde være noget til hinder for at tolke navnet som et oprindeligt "Niorthar akær", guden Njords ager. Mere tør jeg ikke sige herom. En kendsgerning er det dog, at de to jordstykker er så små og ubetydelige, at den en hel mils vej derfra liggende Bjolderup kirke ikke har kunnet få økonomisk udbytte af dem.

Jeg opfatter de to små marker som stedet for den gamle tingplads og således jord, der ikke tilhørte nogen eller omvendt var i alles eje, og den eneste institution, til hvem disse jordstykker kunde overdrages, var da sognekirken. Om »Noracker« i Lyseg hedder det, at den var »indstenet«, d.v.s. afgrænset med spredt liggende kampesten, og således henlå den endnu i slutningen af 1940'erne, da jeg var på stedet. Jordstykket "ved Hestehaverne « bar senerehen det romantiske navn »Baldursborg “ på grund af nogle volde i terrænet. Men da man i 1937 ønskede at grave mergel på dette sted, blev Vilhelm la Cour bedt om at undersøge stedet. Han kunde hurtigt fastslå og med rette, at der ikke var spor af en bebyggelse på dette sted. Der var derfor intet til hinder for mergelgravningen! Derved blev et fortidsminde ødelagt, nemlig markeringen af den gamle tingplads.

Da jeg engang på opfordring af Historisk Samfund for Sønderjyllands daværende formand, amtslæge Lausten-Thomsen, foreviste stedet for kulturhistorikeren Hugo Matthiessen, afsluttede denne min forevisning med på sin arrogante facon at sige: "Ja, det er jo nok, som jeg i sin tid skrev i min bog "Hærvejen«, at tinget flyttedes efter tid og lejlighed, alt efter fra hvilket verdenshjørne blæsten kom!«

Vor viden nuomstunder om vore forfædres gøren og laden i vikingetid og tidlig middelalder giver dog et andet billede. I stedet for tilfældigheder var der tale om en langt større præcision, end Hugo Matthiessen kunde ane. De volde, der gav anledning til en senere tids romantiske opfattelse af en "Baldursborg", fortæller sammen med de to små stykker kirkestuf, at man har vidst, hvor på Urnehoved-banken landstinget skulde finde sted.

Jeg mindes endnu museumsinspektør Hans Neumanns overraskelse over den brede vej, der dengang forbandt de to stykker kirkestuf: "Det er dog en usædvanlig bred markvej, som de Bolderslever her holder sig«. Mon det er tilfældigt?

Min interesse for Urnehoved horer hjemme i årene 1947 til 1951, men ak, hvad kom der ud af det? Jeg havde dengang ikke mod til at få rejst en fredningssag, tiden var heller ikke til den slags. Siden da 
er der handlet ilde med Urnehoved. Allerede i 1937 havde man som nævnt ved mergelgravning ødelagt den vold, der havde markeret tingstedets plads, og som i 1800-årene efter Bolderslevs formodede grundlægger havde givet anledning til navnet "Baldursborg". Den landejendom, på hvis jord mergelkulen ligger, har, siden den blev bygget ca. 1870, båret navnet »Nyborg « (»Neuburg « i den tyske matrikel), og sådan hedder ejendommen den dag i dag til forskel fra det gamle og nu forsvundne voldanlæg "Baldursborg«.

Den brede markvej ind mod "Lyseg" med "Noracker", som havde forbavset Hans Neumann, er for den første halvdels vedkommende blevet taget ind til dyrkning og følgelig gjort til en almindelig smal markvej. Det skete i 1970'erne, da man fra landbrugets side mente, at vort lands dyrkningsareal burde udvides. Denne opfattelse kom også til at bringe dødsstødet for det lille "indstenede « markstykke "Noracker«. Dette lille jordstykke lå i et grønområde op til skoven "Lyseg“ og havde næppe nogensinde kendt en plov.

Men sådan skulde det ikke blive ved med at være. Efter kommunalreformen blev der af Tinglev kommune anlagt en sidevej til Hærvejen med navnet "Lysegvej«, og et par landejendomme blev opført ved den nye vej. Derefter kom den jomfruelige grønjord under plov, og den dengang endnu synlige markering med kampesten af den lille rektangulære "Noracker« er derved blevet fjernet én gang for alle.

Man skulde næsten tro, at der hviler en ond skæbne over Urnehoved, eftersom også Geodætisk Institut har vist sig at være i vildrede med, hvad man skal stille op med det sted, som jeg anser for at have været den gamle tingplads, nemlig det stykke kirkelig stufjord, der i 1443 anonymt kaldes »apud Heesthaue« (»ved Hestehaverne«) og af en senere tid "Baldursborg «. På de lidt ældre målebordskort har geodæterne her afsat navnet "Haldensbol " (efter en andel af Bolderslev bymark, nævnt i Knud Snubbes testamente). Endnu langt værre og helt grebet ud af luften er dog anbringelsen på Geodætisk Instituts 4 cm-kort af navnet 》Olmersvold « på dette sted. (Se gengivelsen af kortet i min bog "Toldsted ved Hærvejen «, s. 32-33.) Jeg sendte Instituttet en protest herover og fik som høfligt svar, at man havde spurgt sig for på Aabenraa rådhus. Man havde glemt, at der i Aabenraa både findes et landsarkiv og et museum, altså institutioner, hvis personale har større kompetence end ansatte på rådhuset. I svaret fik jeg løfte om, at fejlen vil blive rettet på senere kort. Om det er sket, ved jeg ikke. Jeg har besluttet at afstå fra yderligere beskæftigelse med stedet! 


\section{Bjolderup sogn ${ }^{3}$}

Mit arbejde med mit fødesogns historie gav mig et nyt og langt bredere perspektiv i forståelsen af vort folks liv gennem tiderne, levendegjort som det blev gennem det lokale samfunds udvikling fra slægt til slægt. Det blev min opgave i samleværket at følge sognets udvikling fra de ældste tider, at gentage min opfattelse af Urnehoved-problemet og at skildre det splittede sogns administrative forhold, hvor Bolderslev som enklave under Haderslev amt havde sin egen ridefoged (ikke at forveksle med en ridefoged på de kongerigske godser), samt særlige sognefogeder for de ejendomme, der hørte under enten Aabenraa eller Tønder amter.

Inspireret af min gennemgang af Bjolderup sogns ældste tider vovede jeg mig frem med en tolkning af egnens gudetro i førkristen tid. Jeg havde ventet en negativ reaktion på dette forsøg, men fra Svend Aakjær modtog jeg en begejstret lykønskning, og den førte til, at jeg blev inviteret på frokost, lige så snart jeg kom til København. Vi skulde $\mathrm{i}$ "Hotel Alexandras« spisesal sidde $\mathrm{i}$ det hjørne, hvor han havde plejet at spise sammen med sin Far, Jeppe Aakjær, når denne var i Hovedstaden. Selv havde han jo fået sin opvækst hos sin Mor, Marie Bregendahl. Min kontakt til Svend Aakjær førte til, at jeg blev medarbejder ved samleværket "Danmark før og nu ", hvor jeg skrev artiklerne Herregårde i Vest- og Sydjylland, samt Lemvig, Struer og Aabenraa.

Skildringen af sognets frigårde - et specielt sønderjysk fænomen optog mig meget. Jeg blev klar over, at min hjemstavn havde en bonde-overklasse, der ikke var i tvivl om sit værd, hvilket også en række påviselige ægteskabsforbindelser vidner om.

Hovedvægten var naturligt nok lagt på skildringen af den gamle landsby, af udskiftningen og af landbruget $i$ al almindelighed, og her blev Hans J. Bertelsen den store bidragyder. Gennem sit grundige arbejde er hans indsats på dette felt blevet et forbillede for alle senere sognebeskrivelser. Hans gennemgang af samtlige gårdes ejerforhold så langt tilbage, som det var muligt, blev utvivlsomt sognehistoriens mest populære afsnit.

Jeg påtog mig skildringen af fremmedherredømmet, af den tid, da Bjolderup sogn ligesom det øvrige Sonderjylland var underlagt preussisk styre. Det var mig meget om at gøre at fremstille denne periode så nøgternt som muligt, men for mig personligt betød arbej- 
det hermed, at jeg fik et dybt indblik i de kår, som ikke blot sognets befolkning, men hele min sønderjyske hjemstavn måtte leve med.

Mit sidste bidrag til sognehistorien blev et tillæg med en gengivelse af ældre aktstykker i oversættelse. Nogle enkelte af disse akter var kendt i forvejen, men det lykkedes også at finde nogle, der ikke havde været trykt tidligere.

Det ældste og mest væsentlige af aktstykkerne var det såkaldte "Knud Snubbes testamente«, der indtager en central plads som lokalt kildemateriale fra højmiddelalderen. Testamentet kendes kun fra en afskrift taget i 1578, og det er denne afskrift, der i 1834 blev publiceret som en del af »Løgum-bogen« i udgiverværket "Scriptores Rerum Danicarum«. Jeg har siden udgivelsen i Bjolderup Sogns Historie ment, at navneformen "Snubbe " skyldes en fejllæsning, der så meget desto lettere har kunnet finde sted, fordi der i middelalderen kendes tre slægter af navnet Snubbe, to sjællandske og en nørrejysk, men ingen af disse synes at have haft forbindelse til det sønderjyske. I de sønderjyske sogne, hvortil Urne-slægten havde hjemstedsret, forekommer jævnligt slægtsnavnet Snafs. Eksempelvis optræder de to slægter på samme tid $\mathrm{i}$ to så langt fra hinanden liggende sogne som Bjolderup i Rise herred og Vodder i Hviding herred. Jeg har med støtte i dette forhold dristet mig til at mene, at "Snubbe« i Løgumbogen skyldes en fejllæsning for »Snabbe«, »Snabe« eller »Snafs«. Lad denne påstand være det sidste $\mathrm{i}$ mit arbejde med mit fødesogns historie.

\section{$1848^{4}$}

Året 1848 er i Sønderjyllands og det ovrige Danmarks historie blevet »det mærkelige år«. Det var året, der i den sønderjyske befolkning bragte et åbent brud mellem dansk og tysk. Som ung gymnasielærer ved min gamle skole i Aabenraa havde jeg min næsten daglige gang i Landsarkivet, og som uddannet historiker og født sønderjyde følte jeg det som lidt af en forpligtelse at skaffe øget viden om baggrunden for det skel, som vi sønderjyder endnu dengang - nemlig i hundredåret for 1848 - ikke kunde undgå at mærke i det daglige liv.

En stor del af materialet til mine store og små afhandllinger fandt jeg i de dengang endnu delvist uordnede amtsarkiver, og det blev mig her muligt at fremdrage en række vidnesbyrd om, hvorledes man i den jævne landbefolkning traf sit valg i den strid, som udråbelsen 
af den provisoriske regering i marts 1848 havde vakt. Et udsagn fra Bjolderup vestersogn, der hørte til Slogs herred, hvor befolkningen havde valgt den slesvig-holstensk indstillede Thies Steenholdt til stænderdeputeret, fortæller, at et forsøg på en skatteinddrivning til fordel for denne regering, nok kunde få stemningen til at vende. »Hvor jeg kommer, er Folket lidt vranten«, fortæller den derværende sognefoged. »Er Du Provisorisk? Vi har ikke noget med Tydskerne at bestille. Den provisoriske Regjering kjender vi ikke; den har os ikke noget at befale o.s.v.

Under dette opgør vandt også betegnelsen »hjemmetysker « frem, vist oprindelig som en spotteglose, idet man dengang ikke hermed forstod personer med tysk hjemmesprog, men tilhængerne af, at deres hjemstavn, hertugdømmet Slesvig, skulde optages i det Tyske Forbund. Hjemmetyskere var dem, der vilde gøre hjemstavnen til en del af Det Tyske Forbund, skabt af Wiener-kongressen i 1815.

Siden hen er betegnelsen "hjemmetysker" blevet synonym med den tyske minoritet $\mathrm{i}$ den danske del af Sønderjylland. I vor tid omfatter den ikke alene den her omtalte befolkningsdel, der som følge af begivenhederne $\mathrm{i}$ årene omkring 1848 valgte at vende sig mod den såkaldte "danisering ", men også de mange, der i løbet af fremmedherredømmet blev tysksindede som et resultat af uddannelse og embeder, og dertil naturligvis så godt som alle sydfra indvandrede. Det er disse tre komponenter, der i vor tid udgør hjemmetyskheden.

\section{Dansk og tysk ${ }^{5}$}

I hundredåret for 1848 og de følgende år forsøgte jeg at kaste lys over nogle enkeltpersoners nationalpolitiske valg. I flere tilfælde kunde jeg her, bygget på hidtil ukendt kildemateriale, korrigere eller i hvert fald supplere tidligere opfattelser, og jeg kunne belyse den baggrund, der lå bag, at bestemte personer valgte at tilkendegive sig som dansk eller tysk.

De mange artikler, der overvejende blev bragt i "Sønderjysk Månedsskrift« skyldes, at tidsskriftets redaktor Werner Christiansen ofte var i stofmangel. I flere tilfælde lod han derfor indlæg genoptrykke, som jeg $\mathrm{i}$ forvejen havde fået offentliggjort som kronikker $\mathrm{i}$ datidens to lokale aviser, »Hejmdal« og »Jydske Tidende«, der havde Bjørn Hanssen og Morten Kamphövener som redaktører.

Mine bidrag til "Sprogforeningens Almanak" skyldes personlig op- 
fordring hertil af bibliotekar Jakob Petersen, dengang formand for Sprogforeningen. "De har vel ikke noget, som jeg kan bringe i Almanakken «, lød hans opfordring gerne. Vi havde mange gode samtaler. Jeg mindes endnu hans bedømmelse af den sydslesvigske danskhed, der så uventet voksede sig stærk umiddelbart efter befrielsen. Ingen skulde være i tvivl om, at han var H.P. Hanssens svorne rorgænger.

Mit betydeligste bidrag til »Almanakken« er nok skildringen af Nis Hanssen »Bondesøn«. Han hørte ikke til kredsen omkring Chr. Flor og er derfor blevet overset. Hans skæbne var tragisk. Efter kampårene endte han som en nedbrudt mand et par år efter krigsåret 1864. Jeg havde egentlig tænkt mig at skrive en større afhandling om ham, men denne tanke må jeg overlade til en anden at virkeliggøre.

En ret så pudsig lille ting $\mathrm{i}$ »Almanakken« er en omtale af den ellers så fredelige B.S. Ingemanns bidrag til nationalitetskampen. Der var unægteligt langt fra det velbjergede digterhjem i Sorø til Nis Hanssens usikre tilværelse.

\section{»Rigsdanske« embedsmænd ${ }^{6}$}

Efter Treårskrigens afslutning i 1850 var det den fornemste opgave for de danske myndigheder at få gjort op med den århundredlange fortyskning af det gamle hertugdømme Slesvig. Grænselandet skulle "daniseres", som det dengang hed, og til dette formål kom i høj grad præstestanden ind i billedet. De mange præstekald, der var blevet ledige efter afskedigelsen af de hidtidige præster, blev overvejende besat med kandidater fra Kobenhavns Universitet, og deres begreb om forholdene syd for Kongeåen og Kolding Fjord kunde ofte ligge på et meget lille sted.

Det var som regel ret tilfældigt, hvilke af disse skæbner jeg kom i lag med. Det gjaldt f.eks. de to nabopræster, Kok i Burkal og Lützhøft i Bylderup sogn. Kok, der i sin daniseringsiver havde ændret sit familienavn Koch til Kok og forsøgte at ændre sine sognebørns familienavne, f.eks. Roth til Rød, fik en mere besværlig indgang i sit sogn end Lützhøft, og gav sig i lighed med mange af sine kolleger i det sydslesvigske i lag med et forfatterskab, en erstatning for den manglende kontakt med den stedlige menighed.

Min beskæftigelse med Marckmann og Mørk Hansen skyldes derimod ikke en tilfældighed, men var en følge af mit arbejde med Laurids Skau. 


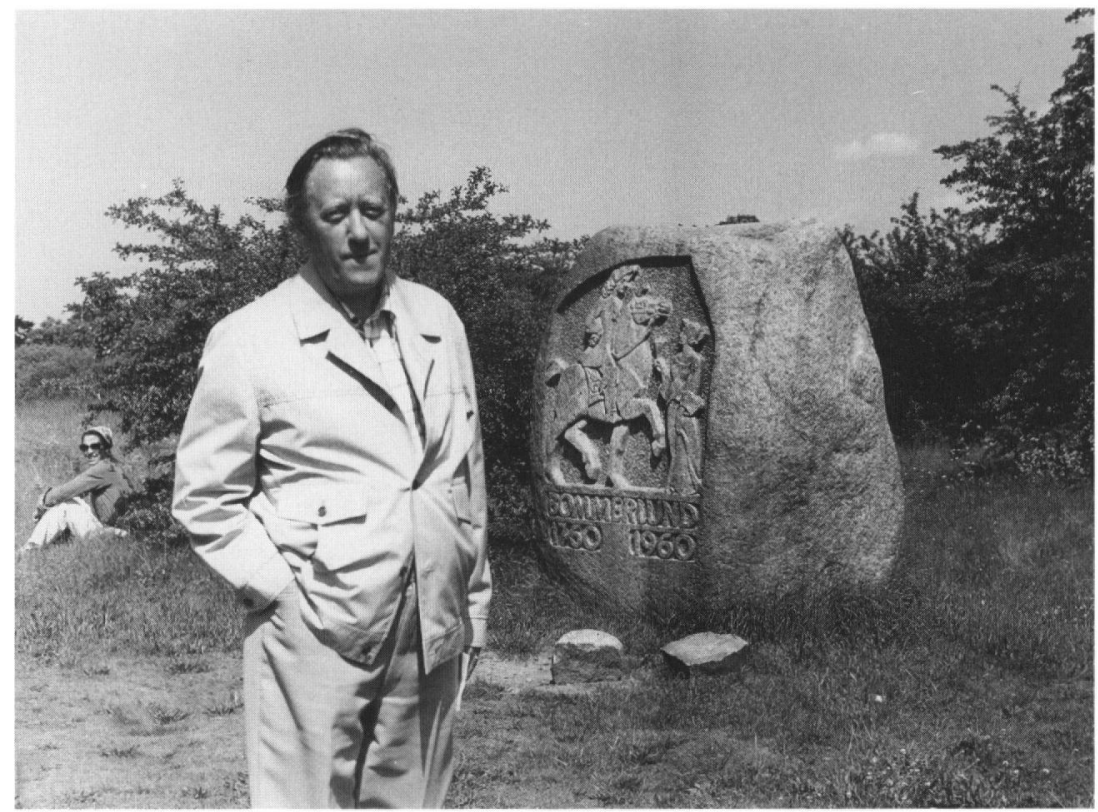

H.V. Gregersen fotograferet ved Bommerlund-mindestenen den 23. juni 1974. Foto $i$ Institut for Sonderjysk Lokalhistorie.

Marckmann og Skau havde i mange år været nære venner, men venskabet hørte op, da fru Marckmann døde i barselsseng efter fødselen af en dreng, som Skau var far til. For Mørk Hansens vedkommende gjaldt hans bekendtskab med Skau først og fremmest deres fælles politiske virke i stændersalen i Flensborg. Jeg fandt heri et kærkomment alternativ til historikeren P. Lauridsens negative vurdering af Laurids Skau.

Mørk Hansens erindringer lå hos hans dattersøn, proprietær Vyff til Paulinesminde i Vonsild, og gennem denne mand fik jeg et levende indtryk af den storbondestand, der var karakteristisk for det gamle Haderslev østeramt. Når han besøgte mig, skulde chaufføren vente ude i bilen. "Han er min tjener", sagde han.

Mørk Hansen selv placerede sig i forfatningskampens år i det yderste Højre og forfægtede standpunkter, som tiden var løbet fra. Højskoleforstander Hans Lund, som dengang var medlem af Historisk Samfund for Sønderjyllands skriftudvalg, sagde efter bogens fremkomst til mig, at der var andre end Mørk Hansen, der søgte at forfæg- 
te ungdommens idealer. Han tænkte på sig selv. På hans tid var det højskolerne og landboerne, der var de trængte.

Flere af de nye præster nordfra måtte sande, at deres sognebørns respekt for dem var en anden end den, de kunde forvente i Kongeriget. Herman Bangs fader oplevede, at hans sognebørn, alsingerbønderne, ikke undså sig for at udnytte hans mangel på økonomisk sans under forhandlingerne om en tiendeafløsning. Da præsten beklagede sig til sin biskop Jørgen Hansen, selv af sønderjysk bondeslægt, irettesatte denne ham med ordene: "Det gælder om at have det rette greb om tingene! « - Gode ord at lægge sig på sinde!

\section{Aabenraa $^{7}$}

Næppe var 1. halvbind af Bjolderup Sogns Historie udkommet i 1951, før jeg fik en opfordring fra Historisk Samfund for Sønderjylland v/ Johan Hvidtfeldt og Peter Kr. Iversen til at blive bidragyder til en Aabenraa bys historie. Min opgave skulde være at skrive byens middelalderhistorie indtil 1523. Jeg gav mig straks i lag med arbejdet, selv om jeg netop var flyttet til Struer som adjunkt ved det derværende Statsgymnasium (dengang eneste højere læreanstalt mellem Thisted og Tarm og mellem Vesterhavet og Viborg). Dette hindrede mig dog ikke $\mathrm{i}$ at opretholde kontakten med det historiske arbejde i Sønderjylland.

Efter at jeg havde afleveret manuskriptet med min andel af byhistorien, fik jeg af Hvidtfeldt en opfordring til at påtage mig en endnu større del af det påtænkte værk. Da flere af de andre forfattere sprang fra, endte det med, at jeg måtte påtage mig at skrive om tiden 16601720 og 1814-1848.

Under skildringen af Aabenraas ældste historie fik jeg brug for de erfaringer, som jeg havde erhvervet mig under arbejdet med Urnehoved-problemet, nemlig opfattelsen af »det kontinuerlige« $\mathrm{i}$ vor historie, et emne, som jeg mange år senere havde lejlighed til efter opfordring at uddybe $i$ en artikel, der afsluttede første årgang af Andreas Michaelsens "Stambladet $«$.

Det blev mig klart, at moderbyen til Aabenraa, den forsvundne landsby Opnør, havde ligget omkring Vægterpladsen og havde haft sin sognekirke, hvor Skt. Nikolai nu ligger. Det er nemlig højst besynderligt, at Aabenraa efter ødelæggelsen i 1247 havde sin bykirke liggende uden for sin stadsgrav. Det er efter min mening et udtryk for 
det kontinuerlige: folk ønskede at blive begravet, hvor de altid havde gravlagt deres døde, nemlig på gravpladsen uden om deres sognekirke, som de nu genrejste i sten, efter at Opnørs trækirke var gået til grunde under kampene.

Landsbyen Opnør blev ikke genopbygget. De overlevende efter kampene har kunnet slå sig ned som landmænd i Kolstrup eller som fiskere og håndværkere i bysamfundet Aabenraa, "Opnør (ved) å«, Opnerå.

Ved at indtegne 2-meters kurven langs med vandet, fjorden og åen, fik jeg hold på bysamfundets oprindelige gadestrøg fra Gildegade over Fiskergade og Søndertorv til Slotsgade. Det var under et af mine ophold i Slesvig by, at jeg blev klar over, hvorledes det var gået til. De gamle ejendomsmatrikler i bydelen Holm strakte sig ned mod Slien, og det betød, at stedets beboere kunde have deres huse så højt oppe, at de ikke var udsat for oversvømmelse, alt imens de nede ved Slien havde deres fiskerfartøjer trukket behørigt op fra havstokken. Netop således havde beboerne langs med det nævnte gadeforløb i Aabenraa indrettet sig. En smuglerhistorie fra 1600-årene, som jeg tilfældigt fandt, oplyser, at en beboer i Slotsgade endnu på den tid havde sit fartøj liggende i Mølleåen. Dermed var min opfattelse bekræftet, og arkæologen Lennart Madsen fra Haderslev Museum har senere ved sine gravninger konstateret, at de fundne matrikelskel går tilbage til byens første tid. Jeg skylder måske at tilføje, at det var salt, der forsøgtes indsmuglet!

Det var vel helt naturligt, at jeg $i$ årenes løb jævnligt kom til at beskæftige mig med Aabenraa, den by, hvor jeg tilbragte min skoletid. Med den Günderothske Stiftelse og Postmestergården i Sondergade tangerede jeg ovenikøbet mit andet interessefelt: Toldsted.

Postmestergården er bygget som et lille rokokopalæ af postmester Linde og i sig selv en turistattraktion, der eventuelt kunde markedsføres som »Postmester Lindes Palæ«. Men det har rette vedkommende i Aabenraa ingen sans for. Man holder fast i betegnelsen "Postholdergården«, et mere romantisk navn, der i sin tid blev benyttet af Hugo Matthiessen i hans ukendskab til den sociale forskel på en postmester og en postholder. Postholderiet, hvor hestene blev opfodret og havde staldplads, lå i et nu nedrevet bygningskompleks ved Mølleåen på den anden side af Sondergade. At der også er en staldbygning bag ved Postmestergården svarer til, at en lignende rangsperson i vor tid har bil med garage, og det har følgelig intet med Postholderiets staldplads at gøre. 
Et andet fornemt bygningsværk kunde Rådhuset være blevet. Vort lands dengang førende arkitekt C.F. Hansen havde nemlig i sin egenskab af overbygningsdirektør leveret et par tegninger, som jeg fandt i Rigsarkivet. Var hans forslag blevet fulgt, vilde Aabenraa have haft en arkitektonisk perle i nyklassicistisk stil. Men sparehensyn tvang byens vise mænd til $i$ udstrakt grad at gøre brug af materialer fra fysikus A.W. Neubers nedlagte badeetablissement. Resultatet blev det nuværende rådhus, der dog som bygningsværk betragtet også har sine kvaliteter.

Min første større afhandling i "Sønderjyske Årbøger« er et udtryk for min interesse for Aabenraas ældre historie. Den blev i 1949 bragt under titlen "Bidrag til Aabenraas økonomiske historie indtil ca. $1730 \ll$ og indbragte mig en pris fra »Dansk Historisk Fællesforening «.

Afhandlingen hvilede hovedsageligt på regnskaberne over den såkaldte "licent «, en havnetold, der registrerede, hvilke varer skibe fra og til Aabenraa havde om bord, og hvilke destinationer de aabenraaske skippere havde. Det var her iøjnefaldende, hvor stor en rolle den politiske kontakt mellem Gottorp og Sverige spillede. Aabenraa blev den førende importhavn for svensk tømmer, især fra Västervik, men $\mathrm{i}$ årenes løb udvidedes byens fragtfart til også at gælde England, hvor Aabenraa (sammen med Flensborg) blev importør af engelsk salt fra især Liverpool.

Krig er som bekendt ikke befordrende for handel. Det måtte aabenraaske skippere sande under de store søkrige på begge sider af år 1700 , men de klarede sig uden om de værste politiske skær ved at medføre to forskellige søpas. I det ene betonedes det, at de var hjemmehørende i det "suveræne hertugdømme Slesvig og ikke hørte til det danske Rige«. Det var velegnet, når en svensk havn skulle anløbes! I det andet hed det, at skibet var hjemmehørende i det »suveræne og neutrale hertugdømme Slesvig, som ikke hørte til det Romerske Rige«. Under den spanske arvefølgekrig (1701-1713), da Frankrig var i krig med det Tysk-Romerske Riges kejser i Wien, var det særdeles anvendeligt, når en fransk havn skulde anløbes!

Kendt af alle antikvitetsinteresserede er de standure, som urmagerslægten Green fra Aabenraa leverede. I forbindelse med mine salthandelsstudier fandt jeg i Fredericia Strømtoldsregister en lille notits, der oplyser, at en aabenraask skipper engang i 1740'erne havde en buffet med hjem fra Liverpool til en mand, som var »flyttet fra Engeland til Aapenraade«. Jeg formoder, at det omtalte 
møbel var til et medlem af urmagerslægten Green, hvis herkomst hermed bevidnedes.

Museumsdirektør Povl Simonsen i Tromsø offentliggjorde engang nogle klippeindskrifter fra tiden før år 1700. Dem havde han fået tilsendt af sin russiske kollega i Murmansk. Takket være mit kendskab til de aabenraaske licentregnskaber var det mig muligt at korrigere læsningen af et par af disse indskrifter og tidsfæste dem.

Det er småtterier, der her er tale om, men det er den slags tilfældige fund, der har været mig et incitament til et fortsat arbejde med min hjemstavns historie.

Et udtryk for min interesse for Aabenraas historie er naturligvis også udgivelsen af Claus Møllers bykrønike med tilføjelser, ligesom jeg i en anmeldelse måtte påvise visse fejl i en udgivelse af byens skrå fra 1335.

\section{Kliplev $^{8}$}

Min interesse for Kliplev skyldes min fædrene families tilknytning til dette sogn, idet min Oldefar, Nis Hansen Gregersen fra Errested i Bjerning sogn, fik et parcelsted ved Hærvejen på Årtoftmark. Det må have været ca. 1834, da han blev ægteviet i dette år. Han var født i 1809 og kun to år gammel, da hans Mor døde, og kun tolv år, da hans Far efter et nyt ægteskab døde i 1821 midt under den store landbrugskrise. Da han tilmed ikke var sin Fars ældste søn, har han måttet søge hjemmefra og måttet udskifte sin hjemstavns fede østeregnsjord med den sandede jord ved Hærvejen gennem Kliplev sogn. Min Bedstefar og Far blev derved hjemmehørende i Kliplev sogn. Min Oldefar fik ved sin fraflytning fra Errested papir på, hvad han hed, nemlig Gregersen, mens hans slægtninge, der blev i deres hjemstavn, bærer navnet Greisen, sådan som det blev udtalt $i$ folkemunde.

Min interesse for kulturhistorien førte mig blandt meget andet også til læsning af Hugo Matthiesens bøger. Det gjaldt naturligvis hans bog »Hærvejen« fra 1930, der kom i mange oplag, men også hans bog "Snapstinget", der kom i 1946. Det slog mig under læsningen af denne sidstnævnte bog, at der vel også måtte findes en hel del stof om det $\mathrm{i}$ ældre tid så velkendte marked i Kliplev, "Kliple Mærken ", som det hed $\mathrm{i}$ folkemunde, og det viste sig hurtigt, at jeg heri havde ret. Resultatet blev bogen »Messe og Marked«, der kom i hele to, ganske vist små oplag. 
Det var markedets ælde helt tilbage fra middelalderen og dets nøje tilknytning til denne tidsalders Skt. Hjælper-dyrkelse, der fascinerede mig. Endnu længe efter reformationen kendte man denne forbindelse, markederne fjorten dage før Majdag og fjorten dage før Mikkelsdag, altså netop mens de store studedrifter passerede ad Hærvejen. Endnu i 1700-årene anså man »das Markt zu Cliplef « for det "fornemste og considerableste « $i$ alle Kongens riger og lande.

Det lod sig derfor gøre at skrive kulturhistorie om de mange skæbner og tildragelser, der knyttede sig til dette sted. Selv vil jeg aldrig blandt århundredernes mange skikkelser glemme den arme forfrosne og forsultne stakkel, der efter i det kolde og blæsende aprilsvejr at være gået kvæghandlerne til hånde med at se til deres dyr trådte ind i Paulskros køkken for at få sig varmet og den værste sult stillet. Han bad køkkenpigen om at måtte få nogle rester fisk, der kom tilbage fra kroens spisende gæster. Han fik dem ikke gratis, men måtte betale en skilling for gæsternes levninger! Med glubende appetit kastede han sig over dem, drak et krus øl, som han havde varmet over arnens ild, og faldt død om uden at have givet en lyd fra sig. Han var "Jyllænder «, datidens indvandrerproletariat fra hinsides Kongeåen.

\section{Niels Heldvad 9}

Det sønderjyske midterland vest for Aabenraa har altid virket dragende på mig, og på en cykletur gennem denne egn kom jeg til at tænke på, at egnens eneste betydelige forfatter i gammel tid, Niels Heldvad, forlængst var glemt af langt de fleste af egnens beboere. Jeg besluttede da at rette op herpå ved at skrive en bog om ham. Nok havde H.F. Rørdam i sin tid viet ham en større afhandling, men også den var glemt og tilmed vanskelig at få fat $\mathrm{i}$. Som sin samtids utvivlsomt mest læste forfatter var glemselen en skæbne, han ikke fortjente. Da beslutningen forst var taget, var der ikke langt til handling.

Under jævnlige besøg i det Kongelige Bibliotek og i Rigsarkivet pløjede jeg mig igennem hans forfatterskab og andet stof, der vedrørte ham og hans tid, og som tiden gik, blev jeg mere og mere overrasket over at finde frem til et levende menneske med en dramatisk skæbne, der søger sin lige. Mens man i regelen kun finder de ydre data af et menneskeliv fra den tid, åbenbarede Niels Heldvad sig i sine skrifter som et menneske af kød og blod. Han gjorde så sandelig ikke en røverkule af sit hjerte. 
Mit arbejde med Niels Heldvad gav mig et spændende indblik i hans tidsalder, ligesom jeg i flere tilfælde følte et personligt engagement $\mathrm{i}$ hans skæbne. Takket være sine årlige almanakker blev han sin tids kendteste publicist. Hans interesse for astrologien hørte tiden til, men han greb også ind i samfundsdebatten. Det kom til udtryk i hans uforfærdede kamp mod sin samtids pengepugere og i hans uskrømtede støtte til småkårsfolk. Det blev til klager, der lokalt affødte et bondetog til hertugen på Gottorp med ikke færre end 123 af Aabenraa amts bønder. Værre endnu blev det, da han ikke lagde skjul på et kirkeligt ståsted, der i efterreformationens år måtte virke forbavsende på grund af hans åbenlyse sympati for Romerkirken. Også den evangeliske kirke var »den hellige almindelige kirke « og burde derfor kaldes "luthersk-katolsk", hævdede han.

En sådan opfattelse er bemærkelsesværdig, fordi der netop på hans tid foregik en kulturkamp mellem den evangelisk-lutherske tro og den fremtrængende calvinisme, der af mange syntes at være i pagt med "fremskridtet«. Med sit stridsskrift mod calvinismen, der udkom i 1597 som det første $i$ sin art på dansk, bragte han sig i et varigt modsætningsforhold til sin øvrighed, hvor Hertugen havde fået sin opdragelse i det dengang calvinske Hessen. Den ledende i hofkamarillaen mod Niels Heldvad blev hertugens "intimus " (fortrolige), Johann von Wouwern, som Niels Heldvad betegnede som sin "mest fjendtligtsindede hader«. To gange måtte han flygte fra sine to præstekald, Hellevad og Egvad, og når det selv efter Johann von Wouwerns og hertug Johann Adolfs død ikke lykkedes ham at vende tilbage, skyldes det nok, at han var trådt i Christian IVs tjeneste som »kgl. kalendariograf «.

Niels Heldvads verden var den samme som Christian IVs. Den strakte fra det nordligste Norge ned over Danmark og hertugdømmerne til det lutherske Nordtyskland, og ligesom Kongen bevægede han sig tilsyneladende lige let på dansk og på tysk. Men sin fødestavn glemte han ikke, og det glædede ham, når han på sine rejser traf sine landsmænd, "slesvigerne i diasporaen", som han kaldte dem.

Under et foredrag i Hellevad ca. 1960 fandt jeg lejlighed til at nævne, at man i denne by havde mulighed for at mindes andet end det forestående hundredår for 1864, nemlig ved at rejse et synligt minde om Niels Heldvad, født i 1564. Det var den ledende blandt sognets historisk interesserede, lærer Peter Hansen, der sørgede for, at ideen blev realiseret. En skønne dag ringede han til mig og fortalte, at nu 
Mindestenen over Niels

Heldvad, som blev afsløret

27. oktober 1964. Foto $i$ Institut for Sønderjysk Lokalhistorie.

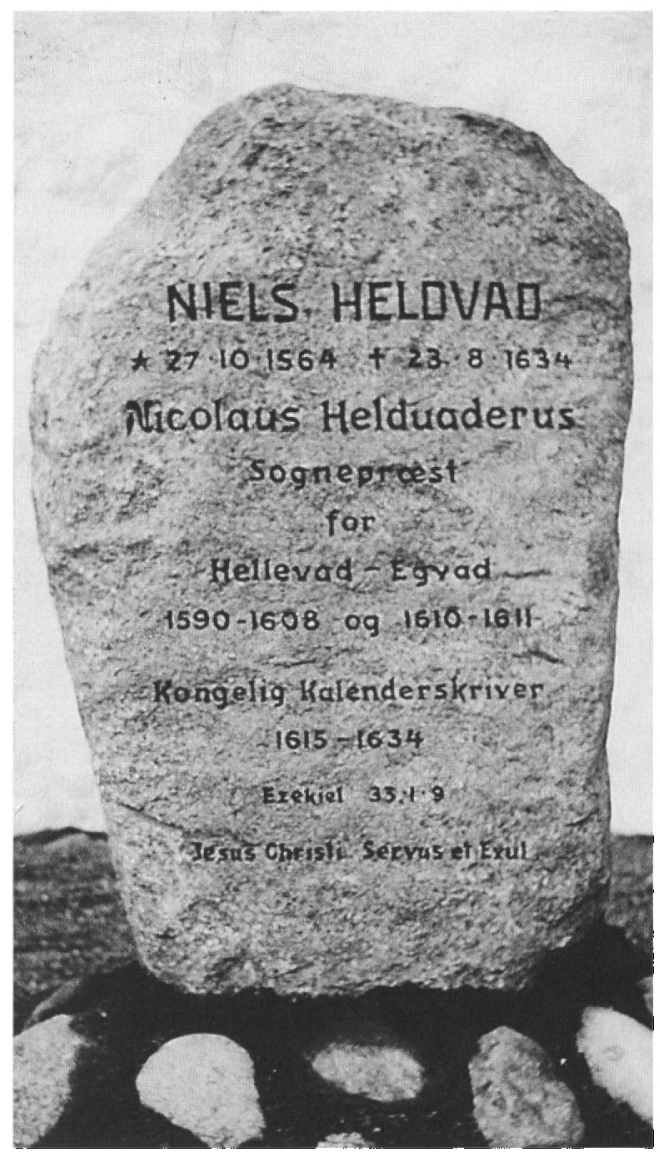

havde de fundet en passende sten, og om jeg vilde komme med et forslag til en inskription. Selve afsløringen af mindestenen fandt derefter sted søndagen lige efter Niels Heldvads fødselsdag den 27. oktober. Urban Schrøder fra Varnæs holdt på grund af en vakance i præsteembedet i efteråret 1964 prædikenen, og det var han den rette til.

Netop som min bog var udgivet, fik Troels Fink, dengang generalkonsul i Flensborg, besøg af Richard Todsen, pensioneret Landgerichtsdirektor og søn af Flensborgs Oberbürgermeister $\mathrm{i}$ årene omkring 1920, og Fink benyttede lejligheden til at forære ham min bog. Med den så ofte omtalte tyske grundighed gav Richard Todsen sig uopfordret $i$ kast med at oversætte min bog til tysk, og vi fik derved 
mange gode stunder sammen i det Todsenske hjem på Stuhrs Allee i Flensborg. Jeg lærte en mand at kende, der uden at give afkald på sin egen tyskhed ønskede nær kontakt med det danske. Troels Fink fandt, at oversættelsen, foretaget af en søn af en gammel danskerhader, var et politicum, og han skaffede derfor midlerne til trykningen. Den uforglemmelige Poul Kürstein stod for den tyske udgaves fornemme udstyr.

Under mine rejser rundt omkring $\mathrm{i}$ Europa har det moret mig, når lejlighed bød sig, at opsøge de store kendte biblioteker for at få et indtryk af deres kapacitet ved at undersøge, hvad de har liggende af bøger vedrørende sønderjysk og/eller slesvig-holstensk historie. Ved en sådan lejlighed blev jeg unægtelig meget forbavset, da jeg i London i British Museums bibliotek fik udleveret et eksemplar af Niels Heldvads historiske hovedværk og fandt det lige så frisk og ubenyttet, som om det lige var hentet hos boghandleren. Men ikke nok med det! Bogen, der har været ejet af Niels Heldvads søn, provsten i Svendborg, rummer en del håndskrevne tilføjelser, der alle tyder på, at det drejer sig om oplysninger, som forfatteren - i dette tilfælde Niels Heldvad - trods sin frimodighed kan have haft sine grunde til ikke at lade udkomme på tryk.

\section{Nogle åndspersonligheder ${ }^{10}$}

Sønderjyllands bidrag til ældre tiders åndsliv må alt i alt siges at være ringe. Niels Heldvad er med sit omskiftelige liv fra det sønderjyske til Hovedstaden nok den mest fremtrædende repræsentant, men ellers er det lidt småt med litterære personligheder fra det sønderjyske, og de tilhører for de flestes vedkommende det tyske åndsliv.

Petrus Generanus, hvis slægt efter navnet at dømme var hjemmehørende i landsbyen Genner mellem Aabenraa og Haderslev, nævnes gerne som en af de mere betydende, men ganske med urette. Som kongelig stipendiat $\mathrm{i}$ Wittenberg skaffede han sig penge til sit underhold ved at forære sine "ofre" en nyligt udkommet bog i fornem indbinding. Senere har man troet, at det var bøger af egen produktion, han skænkede bort. Han klæbede til reformationens hovedby, men Melanchthon og Bugenhagen vilde have ham tilbage til hans hjemstavn. Da Generanus indså, at han ikke kunde blive, hævdede han, at han skulde hen et sted, hvor der blev prædiket på tysk. Derved undgik han ansættelsen $i$ et landsogn, og ad den vej blev han 
ansat som førstepræst og provst i Aabenraa. Set ud fra dette perspektiv er han en ikke uinteressant personlighed!

Præstesønnen fra Skærbæk, Hans Jacobsen Skierbek, blev en kendt læge i Lübeck. Hans forkærlighed for filippismen (efter Philip Melanchthon) gjorde, at en tilbagevenden som præst til hans evangelsk rettroende fødestavn måtte lades ude af betragtning. Også han blev derved en ikke uinteressant personlighed!

Troels Arnkiel, tolderens søn fra Toldsted ved Hærvejen og mangeårig provst i Aabenraa, er Sønderjyllands mest markante repræsentant for barokken. Derom vidner hans store antikvariske værk om Cimbrerfolkets fortid, men hans betydeligste indsats blev hans grundige gennemgang af konfirmationens historie, ligesom hans indførelse af denne kirkelige handling i sit provsti i 1682 har givet ham en varig plads i Sønderjyllands kirkehistorie.

Med biskoppen i Ribe, salmedigteren Hans Adolph Brorson, har vi det mest fremtrædende udtryk for Sønderjyllands danskhed. Som hjemmehørende $i$ enklave-sognet Randerup fik han sin uddannelse på Københavns Universitet via Ribe Latinskole. Den daværende redaktion for Sønderjysk Månedsskrift ønskede at bringe stof fra så vidt muligt alle egne af landsdelen. Takket være det årlige register kunne Månedsskriftets holdere finde snart det ene, snart det andet "glimt" af deres lokalitets fortid. Jeg gengav derfor Brorsons visitatsindberetninger for denne læserkreds.

Jeg tager Johannes Prætorius med blandt den ældste tids »åndspersonligheder «, da jeg finder, at Højst kirkebog for årene 1589 til 1645 er et væsentligt bidrag til vor kulturhistorie. Med dens årlige optælling af de kirkelige handlinger yder den et betydeligt bidrag til vor tids demografiske studier og er derfor blevet benyttet af Ladewig Petersen i Dansk Socialhistorie.

\section{Gotisk skrift ${ }^{11}$}

Under mine arbejder med vor landsdels historie har jeg et par gange kunnet nylæse ældre tekster og ord. Det gælder f.eks. Jacob Langebeks gengivelse i Dansk Historisk Almanak 1775 af Niels Heldvads selvbiografi, hvori det hedder, at hans farmor var født »udi Slosbøl ved Toldsted «. En sådan lokalitet eksisterer ikke, og det må dreje sig om Nybel. Det indledende store N er blevet læst som gotisk Sl, og 
det lille s har været et tegn over o, så det er blevet til et ø. Stedet har altså i Niels Heldvads gengivelse været Nöböl.

Der er flere eksempler på den slags fejllæsninger. Th. Ries og efter ham Carsten Petersen lader provst Hübschmann i Aabenraa holde en ligprædiken på "masurisk «, men det er en fejllæsning for "meissnisch", d.v.s. det højtyske sprog, som den tids kancelli i Meissen i Sachsen brugte. I 1659 oplyser samme provst Hübschmann i anledning af hertugens død, at hans embedsbroder (andenpræsten) talte »densch«, mens provsten prædikede på »dudesch« (tysk). I Black Hansens udgave af »Aabenraa Annaler« er det blevet til nogle sære latinske ord, der ikke giver mening.

Helt tilfældigt reddede jeg samme udgiver for en anden fejllæsning, idet jeg, ligesom jeg kom ind ad døren til Landsarkivet, blev bedt om at læse et ord, og jeg sagde straks, at der stod "Tegelhave«. Det drejede sig om Jørgen Skytte fra Jørgensgård Teglgård. Selv havde Black Hansen en lang notetekst klar med ord, der begyndte med »S«. Jeg mindes endnu, hvorledes landsarkivar Frode Gribsvad vimsede rundt, for han havde læst det samme som Black Hansen.

Under arbejdet med min bog om Niels Heldvad havde jeg også samlet stof i Jacob Fabricius den Yngres optegnelser, men jeg havde hverken mod eller evner til at udgive dette værk. Hertil fandt jeg pastor A. Andersen, der var vendt tilbage fra en gerning som missionær i Indien til en pensionisttilværelse i Haderslev. Han viste sig som den helt rette til at løse opgaven, og senere fik jeg ham også til at udgive Johannes Oldendorphs selvbiografi og Johannes Pistorius' brevveksling. Det var et arbejde, der langt oversteg, hvad jeg ville have været i stand til.

P. Kr. Iversen fik mig til at udarbejde en art lærebog i gotisk skriftlæsning, der samtidig skulle være en nøgle til forskellige arkivalier til den sønderjyske historie. Mine indlæg herom blev først bragt i Sønderjysk Månedsskrift, men derefter i et samlet hæfte. Ideen viste sig at være rigtig. Hæftet blev hurtigt udsolgt, og jeg har siden i flere tilfælde set, at mine fotogengivelser uden smålig hensyntagen til copyright bliver anvendt ved forskellige kurser rundt omkring $\mathrm{i}$ landsdelen.

\section{Navnestof ${ }^{12}$}

Som danskere kan vi glæde os over, at vi er »autochtone«, d.v.s. at vort folk $\mathrm{i}$ sin helhed altid har boet på sin egen jord $\mathrm{i}$ dette vort land. 
Denne kendsgerning fortæller vore stednavne os, og jeg har derfor altid interesseret mig for, hvad vort navnestof er i stand til at oplyse.

Min interesse for den jord, der betegnes som kirkestuf, skyldes oprindelig de to små jordlodder på Urnehoved, der tilhørte Bjolderup kirke. Det forte til, at jeg udarbejdede en art registrant over sakrale stednavne, knyttet til kirkestuf.

Personnavne har også altid haft min interesse. I flere sogne sad der præster, der efter forordningen i 1771 om faste familienavne gjorde, hvad de kunne, for at afskaffe de mange -sen-navne. Resultatet kunde blive højst pudsigt. Familienavne som Lagoni, Fabrin og Mylin stammer fra den tid.

\section{Oksehandel ${ }^{13}$}

Ligesom det var tilfældet med min interesse for salt, var det kombinationen af mit bifag geografi med hovedfaget historie, der førte mig til studiet af andre sider af ældre tiders handelsliv. Det var rent tilfældigt, at jeg i Rigsarkivet stødte ind i en arkivmasse, som jeg ikke siden har kunnet slippe. Som bilag til Aabenraas amtsregnskaber fandt jeg nemlig i en længere årrække i 1600-tallet »Zollrechnung des Ambtes Apenrade«, og jeg blev hurtig klar over, hvad man åbenbart ikke vidste i København, at disse bilag indeholdt opkrævninger af told fra det opkrævningssted ved Hærvejen, der betegnende nok er blevet til stednavnet Toldsted, den store ejendom, som jeg som barn og ung mand i 1920'erne og 1930'erne så ofte har passeret under kørsel fra Bolderslev til Aabenraa og tilbage med min historisk interesserede Far.

De som nævnt hidtil upåagtede toldregnskaber fra Toldsted ved Hærvejen har vist sig at være af overordentlig stor betydning for studiet af 1600-årenes handelsliv. Ejendommen Toldsted med sit dengang store vandingssted ligger nemlig, hvor Gammel Ribervej støder ind $\mathrm{i}$ Hærvejen, og på den måde opsamles her okseeksporten fra de kongerigske toldsteder Ribe, Kolding og Assens, idet åløbene $i$ vest tvang handelen fra Ribe ind mod Hærvejen ved Toldsted, ligesom oksedrivningen over Assens-Årøsund (ofte kaldt »Assens Fehr«) kom ind på Hærvejen ved Immervad.

Hvad der ydermere gjorde toldregnskaberne fra Toldsted betydningsfulde, var ikke alene, at de er bevaret for en række sammenhængende år, men også, at de oplyser, hvem der ejede den enkelte okse- 
drift. Man får herved et enestående kendskab til de pågældende års eksport ud af det Danske Rige. Ikke mindst afsløres den voldsomme nedgang, som efter de "gyldne år « omkring år 1600 skyldes vort lands indblanding $i$ Trediveårskrigen. Mere end lange redegørelser fortæller den aabenraaske amtsskrivers notat, efter at tolderen fra Toldsted som følge af Wallensteins indfald havde måttet flygte fra hus og hjem med kone og børn, på sin egen lakoniske måde: "weile an der Heer-strassen, da er gewohnet, Niemant bleiben kan“. Toldregnskaberne viser også, at det efter krigens år var oksehandlere fra Nederlandene, fra Holland og Brabant, der havde overtaget okseeksporten.

Det var Johan Hvidtfeldt, der foreslog mig at bringe min afhandling i "Jyske Samlinger« 1948. Det blev i det sidste bind, inden tidsskriftet skiftede navn til "Historie«. Til min hjemlige læserkreds fortalte jeg samtidig i "Sønderjysk Månedsskrift « om tolderne på Toldsted og deres skæbne. Lidt for hårdt sluttede jeg min omtale af de ældste toldere med sætningen "Mord og hor, strid og kiv pletter Arnkielernes eftermæle «. Jeg fortrød senere dette udsagn, og det stod mig klart, at jeg engang ad åre igen måtte beskæftige mig med dette sted og dette emne.

Som følge af mange andre gøremål blev det først tredive år senere, i 1978, at jeg barslede med bogen »Toldsted ved Hærvejen«. Takket være den moderne teknik var arbejdet med de gamle regnskaber blevet langt lettere. Jeg fik en bevilling fra Statens humanistiske Forskningsråd til en kopiering, og med adgang til mit hjemlige seminariums regnemaskine kunne jeg gengive de mange tal på okser langt mere præcist, end det før havde været muligt. Jeg skal tilføje, at de mange xerokopier af toldregnskaberne nu befinder sig i Landsarkivet i Aabenraa og er tilgængelige dér.

Det stod mig klart, at en udgivelse af toldregnskaberne alene ikke ville finde ret mange læsere, så jeg besluttede at gøre bogen til et farvel til min tidligste hjemstavn. Endnu engang gengav jeg derfor min opfattelse af Urnehoved-egnens fortid. Desuden var de forskellige tolderes skæbne et oplagt emne, og endelig benyttede jeg lejligheden til at skrive Troels Arnkiels biografi.

Siden da har jeg udarbejdet endnu et par afhandlinger vedrørende oksehandelen. Ved at følge studedrivningen forbi Toftlund toldsted lod det sig gøre at påvise, at hovedparten af eksporten af levende dyr i århundredernes løb er flyttet vestpå, således at Vestjylland endte 
som hovedleverandøren. En anden betydningsfuld kilde ledte professor Ladewig Petersen mig på sporet af, nemlig et regnskab, som okseopkøbere fra Hessen har aflagt i 1508. Det giver et nærbillede af, hvorledes handelen praktiseredes. Som noget ikke uvæsentligt fremgår det af oplysninger herom, at Kancelliet i København allerede dengang var opdelt i en dansk og tysk afdeling. Historikeren Johanne Skovgaard har tidligere ment, at det først skete, da Frederik I blev konge, men efter min mening er denne opdeling blot en naturlig konsekvens af aftalen i Ribe i 1460, der medførte, at dansk var administrationssproget $\mathrm{i}$ kongerigerne Danmark og Norge (med tilhørende øer) og tysk i hertugdømmerne Slesvig og Holsten.

\section{Laurids Skau ${ }^{14}$}

Når jeg fik et nyt undervisningshold på Haderslev Statsseminarium, har jeg altid haft for skik at spørge den enkelte studerende ikke blot om navn, men også om, hvor vedkommende kom fra. Ad den vej fik jeg ry for i løbet af en god uges tid at have et personligt kendskab til de forskellige.

En af de nye lærerstuderende i 1963 hed Peder Skau, og det viste sig, at han var oldebarn af den kendte Peder Skau til Bukshave i Fjelstrup sogn, en bror til Laurids Skau. Jeg sagde til den unge mand: »I må da have nogle gamle papirer liggende derude på jeres gård «, men fik kun et undvigende svar. Et stykke tid senere kom han imidlertidig med en pakke breve til Laurids Skau i 1846 fra snart sagt alle kendte personligheder i kongeriget Danmark. Jeg var helt benovet og foreslog faderen, da jeg kom ud til dem, at de burde udgives. "Ja, men disse historikere havde jo mishandlet mindet om familiens store søn ", hvortil jeg svarede, at ved en udgivelse af brevene kunne historikerne da kun gengive, hvad de indeholdt. Enden blev, at jeg fik lov til at udgive dem og siden aflevere den nævnte årgang til Laurids Skaus privatarkiv i Det Kongelige Bibliotek. Da jeg så dette arkiv, blev jeg endnu engang overrasket. Det indeholder faktisk en pakke for hver årgang lige fra Laurids Skaus første brev til Chr. Flor i 1839 og til hans død i 1864. Kun årgang 1846 var ikke blevet afleveret, uvist hvorfor.

Det vældige brevarkiv gjorde det straks klart for mig, at nu havde jeg fået min sag for. Det var en større opgave, jeg havde rodet mig ind i. Ikke alene skulle de mange breve renskrives, men de skulde også kommenteres, og det var et møjsommeligt arbejde. 
Resultatet af anstrengelserne blev nogle digre bind, sammenlagt $i$ alt 1662 sider. Den omstændige titel »med venner i« etc. skyldes, at jeg ikke på forhånd kunne vide, om Videnskabsfondet, senere kaldt Forskningsrådet, vilde betale for en så stor udgivelse. Et »bind I « ville ligne en torso.

Det stod mig fra begyndelsen klart, at P. Lauridsen i sit værk »Da Sønderjylland vaagnede« havde bedømt Laurids Skau alt for hårdt. Hans tankeverden var den victorianske, mens vi nulevende har vænnet os til, at vore samfundsstøtter kan gøre sig skyldige $\mathrm{i}$ både det ene og det andet, uden at blive jordet af den grund.

Den første historiker, der søgte at rette op på P. Lauridsens dom, var Knud Fabricius, min gamle professor. Da det også var ham, der sørgede for, at jeg kom ind på Regensen og derved sikrede mit udkomme som student, følte jeg det helt naturligt, at jeg tilegnede ham min brevveksling. Jeg fik til gengæld et smukt takkebrev fra den dengang over 90-årige. Et andet takkebrev, skrevet på familiens vegne, modtog jeg fra den ligeledes 90 -årige Marie Elisabeth Schrøder, Laurids Skaus sønnedatter.

Jeg kunne ikke slippe Laurids Skau af mine tanker, dertil fandt jeg hans liv alt for spændende. Efter nogle overvejelser besluttede jeg da at skrive "Sønderjyden Laurids Skaus Livsroman", men jeg blev unægtelig noget forbløffet, da den forlagsredaktør, der stod for udgivelsen og selv var cand. mag. i dansk, over for mig indrømmede, at han aldrig før havde hørt navnet Laurids Skau. Jeg måtte sande Edvard Lembckes ord i afskedssangen til pastor F. E. Boisen i Vilstrup: "Vore navne glemmes som sne, der faldt i fjor".

Men Skau-familien kan nu ånde lettet op. Den forsmædelige behandling, som P. Lauridsen i sin tid havde udsat deres største søn for, er slettet. "Fuld oprejsning til Laurids Skau«, hed det i en anmeldelse af Bjørn Svensson.

\section{Disputatsen $^{15}$}

Til min store forbavselse fik jeg i 1969 af et linjehold i historie på Haderslev Statsseminarium en opfordring til at gennemgå Haderslev på reformationstiden. Det var en ren undtagelse, at jeg af de lærerstuderende fik foreslået at gennemgå et sønderjysk historisk emne. Alt muligt andet har jeg undervist $i$.

Det var utroligt lidt, hvad der fandtes af materiale til dette emne, 
så jeg måtte selv i gang med at finde det stof frem, som naturligt kunde indgå $i$ undervisningen, og jeg glemmer aldrig, hvorledes jeg efter en undervisningstime på vej ned ad en bagtrappe til frokostpausen på lærerværelset oplevede en åbenbaring! Jeg bruger bevidst dette ord, for i et nu blev jeg klar over baggrunden for den sproglige udvikling i senmiddelalderen og frem til reformationstiden. Jeg var straks klar over, at nu var det op til mig selv at skaffe dokumentation for min opfattelse.

Det var den politiske udvikling med katastrofen for det danske rige umiddelbart efter år 1320, og det var den nye danske kongemagts forgæves forsøg på at genrejse sin magt over Sønderjylland, der endte så brat med rømningen af Flensborg i 1431, hvorom det hele drejede sig. Fortyskningen skyldtes ikke en indvandring eller administrationens plattyske sprog, men den tids højere uddannelse af sognenes kvikke hoveder, nemlig de vordende præster, og i Sønderjylland varetog kannikerne ved kapitlerne i Slesvig, Ribe og Haderslev denne undervisning.

Dette blev af varig betydning for eftertidens sprogligt kulturelle udvikling i Sønderjylland, eftersom domkapitlet i Slesvig i begyndelsen af 1300-årene var blevet fortysket. Alle stiftets biskopper kom efter 1308 sydfra. For de unge studerende fra stiftets sogne betød det, at nationalsproget for dem blev det plattyske ved siden af fagsproget latin og den medbragte hjemlige dialekt. Omvendt indtog det danske rigssprog stillingen som »det højere sprog« ved kapitlerne i Ribe og i Haderslev.

Det var denne åbenbaring, som jeg måtte finde bevismateriale til. Emnet var helt klart et politicum, og det blev derfor af betydning for min opfattelse af begivenhedsforløbet, at jeg kunde få mine tanker ud som doktordisputats. En sådan er nu engang det blå stempel, der gør fremstillingen til noget særligt.

Når jeg valgte Odense Universitet til min disputats, skyldtes det dels den kortere afstand hertil fra Haderslev, og dels, at jeg vidste, at her ville bedømmelsesudvalget hurtigst nå til en indstilling. Professor Ladewig Petersen ledede dette udvalg, og mine opponenter blev Troels Fink og docent Tore Nyberg. Det blev til den tidsmæssigt hurtigste doktorafhandling, jeg har overværet. Vi begyndte kl. 14 og trods kaffepause kunne handlingen afsluttes $\mathrm{kl}$. ca. 17. For mig og min kone og børn blev det en god dag, en sjælden solrig vinterdag, Skt. Luciæ dag den 13. dec. 1974. 
Det vil ikke her være rimeligt at referere alle de emner, som helt naturligt måtte indgå i fremstillingen, det være sig den politiske og sprogligt-kulturelle udvikling, den kirkelige udvikling, herunder drømmen om et særligt Haderslev stift etc. Ét emne måtte jeg dog arbejde videre med, nemlig baggrunden for Haderslevs særstilling i forhold til stiftsbyen Slesvig, d.v.s. årsagen til oprettelsen af det særlige kollegiatkapitel, der ledede Barved syssels provsti. Jeg er her senere kommet til den opfattelse - der unægteligt bygger på et meget spinkelt kildemateriale - at provstiet omkring Haderslev oprindeligt har hørt til Ribe stift. Det forklarer, at kollegiatkapitlet i Haderslev var et dansk modstykke til domkapitlet i Slesvig. Dog efter rømningen af Flensborg i 1431 begyndte her en lignende udvikling i tysk retning som den, domkapitlet i Slesvig kom ud for siden 1300-årene. Det var reformationen med dens afskaffelse af kannikevæsenet, der afbrød denne udvikling.

Flensborgs Stadtarchivdirektor, Hans-Friedrich Schütt, der, straks bogen udkom, efter eget udsagn var meget optaget af min fremstilling, beklagede, at kun de færreste af hans landsmænd var i stand til at forstå indholdet. Han fik mig derfor til at skrive en kortere fremstilling af emnet til det værk, der udkom i anledning af Flensborgs 700års jubilæum. Det er også Hans-Friedrich Schütt, jeg kan takke for at have modtaget »Kulturpreis der Stadt Flensburg« i 1980.

\section{Vojens-Tørning ${ }^{16}$}

I 1977 kunne P.J. Schmidts Bogtrykkeri i Vojens fejre et 75-års jubilæum som kommunens ældste virksomhed, og bogtrykker Ludvig O. Schmidt bad mig $\mathrm{i}$ den anledning om at skrive et historisk skrift, der skulle ligge klar til begivenheden. Jeg betingede mig ret til at afslutte min fremstilling ved året 1864, da Vojens blev jernbaneby og dermed trådte ind $\mathrm{i}$ den industrielle tidsalder. Denne tidsalder fandt jeg, at andre kunne tage sig af.

Lokalt kunne jeg i min Vojens-bog udnytte min viden om Hærvejen, senmiddelalderens ødelægning, middelalderkirkerne, de økonomiske, religiøse og politiske forhold og naturligvis ikke mindst Tørning, middelalderens største adelsborg.

Da jeg engang stod oppe på det store Tørning voldsted, blev jeg klar over, at en restaurering af bygningerne neden for voldstedet skulle ske omgående, dersom det hele ikke skulle falde sammen. Jeg skrev 
derfor et brev til Vojens kommunalbestyrelse, hvori jeg gjorde opmærksom på situationen.

Hans Neumann fra Haderslev Museum fik et bygningssyn sat $i$ værk, og en skønne dag fik jeg fra den stedlige »Lions Club« en opfordring til at deltage $i$ et samarbejde, der skulde føre til, at der kunne dannes en selvejende institution. Den ledende kraft $i$ det restaureringsarbejde, der skulde gennemføres, blev Hans Erik Høyer. Det var nemt nok for mig at skrive et brev, men det er Hans Erik Høyer, der bør roses for at have ofret $i$ tusindvis af timer og kræfter på at få de faldefærdige bygninger op at stå. En anden, der fortjener at blive påskønnet, er skovrider J.C. Munkøe, der sørgede for, at Skov- og Naturstyrelsen overtog den jord, der lå til Tørning Mølle, mens selve bygningerne blev overdraget til den selvejende institution.

I en brochure om Tørning fremhæves det, at det var min bog, der havde skabt »en stor lokal opmærksomhed omkring Tørning«, og det har naturligvis kun kundet glæde mig. Efter at en halv snes år var gået med restaureringsarbejdet, og der havde været en indvielsesfest $i$ 1986 med tilstedeværelse af Dronning Ingrid, miljøminister Christian Christensen og undervisningsminister Bertel Haarder, trak jeg mig ud af den selvejende institution. Jeg fik dog forinden Bertel Haarder til at forestå afsløringen af den mindesten for Tavlesagen i 1841, som jeg ud fra min Laurids Skau-interesse havde fået anbragt på Tinghusets tomt.

Jeg kan til slut ikke lade være med at fortælle, at jeg i min første omtale af Tørnings sidste tid gjorde opmærksom på, at der efter Wallensteins indfald i 1627 alene var tale om krigsødelæggelser af Ladegården og af Møllen, men ikke af Borgen. Jeg fastslog derfor, at Tørninghus måtte være blevet ødelagt inden krigen. Men netop som jeg skulde læse sidste korrektur, fik jeg tilsendt "Ribe-bispen Peder Hegelunds Almanakoptegnelser«, og heri læste jeg om den 9. marts 1597: »Taarninghuss affbrende altsammen«. Jeg var selvsagt glad for, at denne særdeles vigtige oplysning kunde blive indføjet $\mathrm{i}$ den sidste korrektur, før bogen gik i trykken.

\section{Ødelægningen i senmiddelalderen ${ }^{17}$}

Det var førstebibliotekar ved Det kgl. Bibliotek Svend Gissel, min studiekammerat fra de unge år, der i 1971 fik mig med i Det Nordiske Ødegårdsprojekt, hvor han var leder af den danske afdeling, og det 
var hans tanke, at jeg skulle deltage, fordi Sonderjylland skulle have sin egen underafdeling. Et samarbejde mellem historikere, geografer og stednavneforskere skulle åbne op for større viden om vort samfund i senmiddelalderen.

Som kriseforskningens Nestor deltog også C. A. Christensen, der havde sammenlignet Slesvig domkapitels regnskaber fra 1435/39 med kapitlets jordebog fra 1352 i afhandlingen "Krisen på Slesvig Domkapitels Jordegods « $i$ "Historisk Tidsskrift « 1960/62. Det var en afhandling, som alle, der interesserede sig for emnet "den senmiddelalderlige krise«, anså for den tids vigtigste forskningsresultat.

I forbindelse med udarbejdelsen af min disputats fra 1974 studsede jeg over, at 1352-jordebogens stednavne i den iøvrigt latinske tekst var udpræget danske, skønt det slesvigske domkapitel på den tid (efter Gerhard IIIs, den kullede greves tid) var blevet overvejende tysk. Jeg skønnede derfor (i nævnte værk note 162), at denne jordebog måtte være en gengivelse af et ældre forlæg, antagelig fra Valdemars-tiden, og at året 1352 derfor ikke kunne anvendes som sammenligningsgrundlag. Jeg mindes endnu, at C. A. Christensen blev blussende rød $i$ hovedet, da jeg spagfærdigt over for ham antydede min opfattelse, men vi undlod derefter at komme nærmere ind på emnet. At det også var helt galt med hans ligestilling af middelalderens præbende Avbæk med den efterreformatoriske lille bebyggelse Avbæk i Løjt sogn, blev jeg først senere klar over.

I et foredrag på Sandbjerg (trykt i "Danmark i Senmiddelalderen " 1994) gennemgik Svend Gissel mit bidrag til ødegårdsforskningen, og jeg er glad over, at han sluttede omtalen med ordene: "I øvrigt yder Gregersen C. A. Christensens afhandling fuld honnør«.

Det viste sig efterhånden, at egnen omkring Vojens, denne sandede hedeslette, var som skabt til at være forsøgsmark for studiet af ødelægningsprocessen.

Hertil fandt jeg i høj grad støtte hos pollenanalytikeren Bent Aaby, som opsøgte mig efter at have læst min bog om Vojens. Han var i færd med at undersøge Abkær mose og kunne påvise egnens klimatiske udvikling gennem 6000 år. For mig var det selvsagt en tilfredsstillelse, at han kunne bekræfte min opfattelse af en klimatisk betinget ændring af levevilkårene i senmiddelalderen.

Til slut en lille oplevelse. Sammen med Hans Neumann var jeg engang ude for at søge den forsvundne Arvad kirke, og ved Træhede blev det os anbefalet at opsege en eneboer, da han var den, der havde 
levet længst på dette sted. Da vi kom til hans brøstfældige hjem, bød han os indenfor med ordene: »I ka jo æ språch «. Neumann og jeg var enige om, at i sådanne tilfælde var det godt at kunne snakke sønderjysk. Eneboeren oplyste, at der i en nærliggende mark var et bestemt strøg, hvor afgrøderne, enten det var korn eller roer, voksede bedre, og Neumann og jeg var da enige om, at det måtte være kirkegården ved Arvad, der havde sat sig disse spor. En rendegraver afslørede dog hurtigt, at der var tale om en vold gennem terrænet. Jeg satte mig i forbindelse med oberst Ejlif Schneider, Flyvestation Skrydstrup, som jeg kendte flygtigt, og fik ham til at lade en helikopter flyve hen over stedet med en fotograf. Stor var overraskelsen, da luftfotografierne viste, at der var tale om et kilometer langt voldanlæg tværs over Hærvejsstrøget, som netop her i en gammel indberetning kaldes Savsevejen, d.v.s. vejen ned til sakserne (tyskerne). At en sydvestlig afbøjning af denne vej umiddelbart syd for min fødeby Bolderslev hedder Friservejen, fortæller samstemmende hermed, at her gik vejen ud til friserne.

Opdagelsen af folkevolden tværs over Savsevejen blev således en af tillægsgevinsterne $\mathrm{i}$ forbindelse med min andel af Det Nordiske Ødegårdsprojekt.

\section{Under fremmedherredømmet ${ }^{18}$}

Det var min interesse for Laurids Skau og hans bror Peder Skau, der førte mig ind på brevstof vedrørende danskhedens ledere under fremmedherredømmet. Hvad der kunne forekomme af uoverensstemmelse mellem dem, kom på grund af tidernes tryk ikke frem i offentligheden. Kun i private breve finder man mere eller mindre kraftige antydninger af forskel i opfattelser.

Efter 1864 stod Hans Krüger som danskhedens ukronede konge. Det var især tilfældet i Haderslev vesteramt, hans snævrere hjemstavn. Efter sin død fik han endda en art helgenbiografi, forfattet af Morten Eskesen. Når man ved, hvorledes det gik med Laurids Skaus eftermæle, fandt jeg, at der kunde være grund til at se Hans Krüger nærmere efter i sømmene. Vel vidende, hvad jeg var i færd med, skrev jeg min afhandling $i$ "Festskrift til Johan Hvidtfeldt « med støtte i forskellige brevudtog.

Alligevel skulde det vise sig, at man ude i vesteramtet fortsat ikke tålte, at der blev rejst spørgsmål ved Hans Krügers personlige habi- 
tus. Min iøvrigt gode ven, den alt for tidligt afdøde sparekassedirektør og lokalhistoriker H.P. Jensen, Agerskov, skrev en længere anmeldelse af min afhandling i "Sønderjysk Månedsskrift« 1979, hvori han oplyste, at jeg havde "taget et stykke historie op til revision, som det sjældent er set «. "For år tilbage ville denne afhandling have udløst stærke følelser, og doktoren [det er mig!] ville da næppe have turdet vise sig vest for vandskellet.« Det var stærke ord, men kendte man H.P. Jensens form for humor, var de nok ikke så alvorligt ment.

Mere nid var der i en artikel, som Bevtoft-præsten bragte i Søren Krarups organ »Tidehverv«. Han mente sig beføjet til bl.a. at korrekse mig, fordi jeg havde påvist, at Hans Krügers manglende tyskkundskaber var medvirkende til hans korte ophold i den tyske Rigsdag. Jeg sendte Søren Krarup en replik, som jeg bad om at få optaget. Som jeg skrev: han var jo også selv jævnligt udsat for angreb, som han måtte svare på. Søren Krarup bragte godhedsfuldt min replik!

\section{Slesvig og Holsten ${ }^{19}$}

Kun godt et års tid før 1981 fik jeg en opfordring fra »Politikens Forlag " om at skrive det første bind af en Slesvig og Holstens historie. Det skete utvivlsomt på forslag af Troels Fink, hvem jeg også på grund af hans virke for Sønderjyllands historie fandt det naturligt at tilegne mit bind.

Forlaget ønskede at supplere dets »Danmarks Historie« i 14 bind med nogle bind, som det kaldte $»$ Danmarks historie - uden for Danmark «. Der skulde dels skrives om kolonierne i Asien, Afrika og Vestindien, ligesom der også skulde være et bind, der omfattede Skåne, Halland og Blekinge. I dette projekt indgik to bind om Slesvig og Holsten, og jeg kom ind som forfatter til tiden før 1830, mens grænselandseksperten, professor Lorenz Rerup påtog sig at behandle tiden efter dette årstal. »Redaktion og forlag har følt, at de næunte områders historie har krav på en sammenhængende og langt mere detaljeret fremstilling, end det har været muligt at give i det store oversigtsværk, Danmarks historien ", hed det i forlagets introduktion.

De to bind om Slesvig og Holsten blev en bestseller. Oplaget på 10.000 ekspl. var udsolgt i lobet af kort tid, og det skyldtes jo nok, at der ikke siden den store 5-binds »Sønderjyllands Historie« fra 193143 fandtes et oversigtsværk på markedet. De to nu udsolgte bind er stadigvæk efterspurgte, skal man tro vort lands antikvarboghandlere. 
Rerup og jeg foreslog derfor forlaget et nyt oplag, men forlaget var åbenbart kommet $i$ en ny situation, og det gjorde, at det ikke turde binde an med et nyt oplag, end ikke $i$ form af en paper-back. I min sidste opfordring tilbød jeg at give afkald på et personligt forfatterhonorar, men lige meget hjalp det.

\section{Det nationale ${ }^{20}$}

Den politiske afspænding mellem Danmark og Tyskland efter 1950 afspejledes også i det dansk-tyske grænselands historieskrivning. Man kunne nu med fordel beskæftige sig med de resultater, man nåede til fra begge sider, idet historien ikke mere skulde bruges som et våben i stridighederne mellem dansk og tysk.

Alligevel kunde knaster vokse frem, og så måtte man naturligvis sørge for, at de blev fjernet så hurtigt som muligt. Jeg selv måtte et par gange tage en tørn med Erich Hoffmann, Professor der Landesgeschichte ved Kiels Universitet, da han opererede med de besynderligste teorier om »deutsche Fernkaufleute« og deres virke som bygrundlæggere og dannelse af såkaldte »Nicolai-Patrozinien« i Sønderjylland. En værre vandgang blev professorens omtale af tre ikkeeksisterende kirker i Flensborg.

Men det anførte bør nok betragtes som rene undtagelser og har vel næppe været årsagen til, at jeg i 1985 modtog H.V. Clausens og Johan Ottosens legat til fremme af danskheden.

\section{Haderslev $^{21}$}

Min medvirken i Trap Danmark, Femte udgave, skyldes en opringning fra Peter Skautrup, der var en af redaktørerne. Han begrundede sin henvendelse med, at jeg var den eneste, han kendte i Haderslev. Det blev nu nok sagt i sjov, men jeg slog til. Jeg fandt dog snart, at dette opslagsværks små notitser ikke var noget, der kunne fange min interesse, og jeg fik da Olav Christensen til at afløse mig.

Min lille præsentation af seminariet $i$ Haderslev var noget, som mine kolleger mente, at jeg var selvskreven til. Af nyt har jeg fremhævet, at grundlæggelsen af seminariet ligesom af Haderslevs store kaserne var en følge af, at "paragraf 5 « officielt var slettet siden 1879 . Tyskerne mente nu, at de var kommet for at blive!

Det var den ældre tid, der interesserede mig mest, ikke blot Claus 
Møller, som jeg kendte fra Aabenraas bykrønike, men også i form af de opfordringer, som jeg fik af biskop Thyge V. Kragh om at bringe noget stof til "Haderslev Stiftsbog «. Som afløser for $\mathrm{H}$. Hejselbjerg Paulsen blev jeg medlem af Stiftsbogens redaktion og udarbejdede sammen med Olav Lindegaard, dengang domprovst, en passende turistbrochure for Haderslev Vor Frue Domkirke. Den er siden kommet i flere oplag og foreligger også på engelsk og tysk.

Som borger i Haderslev føler jeg at Haderslev Domkirke er mit andet hjem. I min disputats var det lykkedes mig at fastslå, at nedtoningen af katedralbyggeriet ikke - som hidtil antaget - skyldtes pekuniære forhold, men skete af politiske grunde som følge af den dansk-nordiske kongemagts nederlag med rømningen af Flensborg i 1431. Trods dette var byggeriet dog så langt fremskredet, at kirken bevarede sit katedralpræg, og det har gjort Haderslev selvskreven som stiftsby efter genforeningen i 1920 .

Det var på denne baggrund, at biskop Lindegaard sørgede for, at en afhandling, som jeg skrev til "Haderslev Stiftsbog « 1992, også blev udsendt $i$ et fornemt udstyret gratis særtryk som en hilsen fra Haderslev by og Haderslev stift i $1992 \mathrm{i}$ anledning af 700-året for udstedelsen af Haderslev stadsret. Det siger sig næsten selv, at dette særtryk i løbet af et par dage var revet bort.

Som medlem af Domsognets menighedsråd i 1960'erne fik jeg i 400året for grundlæggelsen af Haderslev gamle latinskole i 1567 og for Hertug Hans Hospitalskirke i 1569 mine kolleger i rådet overtalt til at få disse bygninger restaureret. I dag har alle i Domsognets menighed glæde heraf, og for mig har det naturligvis været en personlig tilfredsstillelse, at det lykkedes.

\section{Reformationen $^{22}$}

Det burde egentlig vække til eftertanke, at der kun er skrevet ganske lidt om Haderslev som reformationsby, om man vil, som "Nordens Wittenberg «. Hans Hejselbjerg Paulsen har i anledning af det danske og norske reformationsjubilæum i 1936 i en afhandling $i$ "HaderslevSamfundets Årsskrift« samlet, hvad man på den tid vidste om byens betydning i kirkehistorien. I 1986 festligholdt Institut for Kirkehistorie ved Kobenhavns Universitet - det var især Leif Grane, Martin Schwarz Lausten og Knud Banning - mindet om reformationsåret. 
Jeg blev indbudt til at deltage, selv om det fra min side var helt tilfældigt, at min bog om reformationen udkom i nævnte år.

Hvad de fleste ikke gjorde sig klart, var hele den sprogligt-kulturelle situation, der herskede i grænselandet på reformationstiden. Haderslev-artiklerne har således ikke, som P.G. Lindhardt mente, først foreligget $i$ en dansk udgave, fordi kirkesproget var dansk $i$ Haderslev provsti. Han og andre med ham forstod ikke, at sognepræstens prædikesprog ude på landet nok var dansk, men hans embedssprog var tysk og hans teologiske lærdomssprog latin, altimens han måske $i$ dagligdagen anvendte sin hjemlige dansk-sønderjyske dialekt. Den første, der antydede dette, var egentlig Th.O. Achelis, med hvem jeg brevvekslede i en årrække.

Reformationens ledende mænd, hertug Christian og hans teologer, indkaldt fra Wittenberg, var alle tysktalende, og Haderslevs betydning bliver derfor, at Martin Luthers kristendomsopfattelse takket være præsternes prædikesprog her bliver gjort tilgængelig for dansktalende menigheder. Afgørende for den kirkesprogsgrænse, der i det store og hele blev vor landegrænse ved folkeafstemningen i 1920, var, at Aabenraa og Tønder provstier blev lagt ind under superintendenten i Haderslev, og at de vestlige sogne et par år senere blev tilbageleveret til Ribe stift.

Som tillæg til min bog om reformationen fik jeg også Haderslevartiklerne udgivet, så der nu er nem adgang til denne ældste grundlov for vor evangelisk-lutherske kirke. Forfatteren er antagelig Johann Wenth, der i sine sidste leveår af sin ven og velgører Christian III blev gjort til biskop over Ribe stift. Hans Wandal blev han her almindeligvis kaldt.

Hermann Tast i Husum bliver ofte fremhævet som en af reformationens hovedskikkelser, og det var han også, men vor egentlige reformator er og bliver hertug Christian i Haderslev, den senere kong Christian III. Det var ham, der ved hjælp af sine indkaldte teologer fra Wittenberg fik afstukket retningslinjerne for det kirkelige arbejde. Derfor kan Haderslev med rette kaldes »Nordens Wittenberg«.

\section{Ensted og Løjt ${ }^{23}$}

Jeg havde egentlig besluttet, at jeg ikke ville deltage $i$ fremtidige team-works, men da Lars Henningsen en dag, jeg sad i Rigsarkivets læsesal, spurgte, om jeg ikke kunne tænke mig at medvirke i Ensted 
og Løjt sognehistorier, sagde jeg ret hurtigt ja. Som indlemmet i Aabenraa kommune efter kommunalreformen i 1970 måtte de to sogne ligesom Aabenraa by have krav på at få deres historie udgivet. Når jeg sagde så gladeligt ja, var det vel også, fordi jeg vidste, at redaktionen med Lars Henningsen og Hans $\mathrm{H}$. Worsøe var i gode hænder, og jeg havde desuden familiemæssig tilknytning til de to sogne. Jeg mente også, at jeg havde et vist forhåndskendskab til de emner, som min medvirken ville komme til at berøre.

I Ensted sogn gjaldt dette valfartskapellet i Årup, i Løjt sogn Johannes Mejers kortværk fra 1641. Nogle af emnerne havde jeg $i$ forvejen beskæftiget mig med, bl.a. i forbindelse med Kurt Hectors udgivelse af en regnskabsbog fra Gettorf i Sydslesvig og Poul Svenssons fornemme bog om altertavlen i Løjt kirke. Min opfattelse af den senmiddelalderlige ødelægning og den sprogligt-kulturelle udvikling kunne jeg også drage nytte af $\mathrm{i}$ de to sognes ældre historie.

\section{Vikingerne ${ }^{24}$}

I 1950'erne sagde jeg ofte, at Slesvig var den by, hvor jeg havde tilbragt mest tid af de byer, som jeg ikke havde været bosat i. Jeg færdedes dengang ofte i Landesarchiv på Gottorp slot, hvor jeg fandt stof til f.eks. Niels Heldvad-biografien og til forskellige afhandlinger, og jeg drømte egentlig også om at samle noget kildemateriale til brug i historieundervisningen i gymnasieklasserne. Heldigvis blev det ikke trykt. Arkæologien går som bekendt frem med stormskridt. Det utrykte materiale, som jeg havde samlet om Danevirke og Hedeby fik jeg dog godkendt af Kjeld Winding som egnet til undervisningsbrug. Jeg benyttede det $\mathrm{i}$ forbindelse med min 2.G.s årlige ekskursion til Slesvig og Lübeck, og det blev en tradition, der fortsatte efter min flytning fra Struer Statsgymnasium.

Det var den tidligste sikre datering af Danevirke til 737, der satte skub i mine skriverier om vikingerne. Med denne datering kunne myten om det lille Danmark, et produkt af vort militære nederlag i 1864, omsider bringes til ophør. Den tidlige datering af Danevirke og den omtale, som vore forfædre fik i »De Frankiske Rigsannaler«, fortæller, at det var Danskerne og ikke Nordmændene, der jævnligt kaldes Normannerne.

I tider med en stærk kongemagt var Danmark en maritim stormagt, som man i Frankernes hovedsæde Aachen vidste at behandle med 
behørig respekt. Det fremgår tydeligt af omtalen af den store flåde på 200 skibe og af den danske kongemagts herredømme over dele af Norge, samt af de jæunbyrdige aftaler, der afsluttedes mellem Danskerne og Frankerne.

Modsat andre historikere har jeg argumenteret for, at den unavngivne ø, som flåden i 815 lå ud for, var Sild eller Føhr. Begge steder finder man her resterne af store ringvoldsanlæg, der desværre endnu ikke har været genstand for en omhyggelig arkæologisk undersøgelse. Fra disse baser kunde Frankernes indfald nord for Ejderen afskæres, ved at flåden gik op i flodmundingerne. Frygten herfor blev realiseret i 815 .

De ældste danske konger, som vi kender af navn, synes at have håndhævet rettigheder over Friserne, og jeg vil mene, at det er sket ud fra ønsket om at sikre sig saltvejen ned mod Baie syd for Loirefloden. I tider med en svækket kongemagt nævnes jævnligt "omstrejfende flåder «, der tog sig selv til rette, og det er dette billede af vikingetiden, der er blevet det populære.

Efter den tidlige datering af Danevirke står det dog fast, at Frankerne efter deres erobring af Sachsernes land havde fået en maritim stormagt til nabo.

\section{Anglerne ${ }^{25}$}

Det var Olmersdiget, der førte mig ind på studiet af Angler-problemet. Olmersdiget, i længde og størrelse kun overgået af Danevirkesystemet, giver alene mening, dersom det har skullet værne en folkestammes enemærker. Da det er et forsvarsværk fra ca. 200 vendt mod en nordfra kommende fjende, må det være nærliggende at tænke på, at der så tidligt har eksisteret et særligt Angler-rige, og at jernalderens store krigsbytteofferfund fra Ejsbøl til Thorsbjerg er vidnesbyrd om kampe, der har fundet sted godt et hundrede år senere, og som må antages at have fort til Angler-rigets undergang.

Jeg viste i 1950 stedet frem for en gymnasieklasse fra Aabenraa Statsskole, hvor jeg dengang var ansat, og ved Almstrup Bæk kunne vi med hænderne udgrave det nederste af en egepalisade. Den fik jeg gravet ned i min Søsters have $\mathrm{i}$ Tinglev, men da den et års tid senere blev gravet op, var den sprunget i mange stykker, så det lykkedes kun den lokale billedskærer Fr. Grube at få en dolk lavet af denne stolperest. 


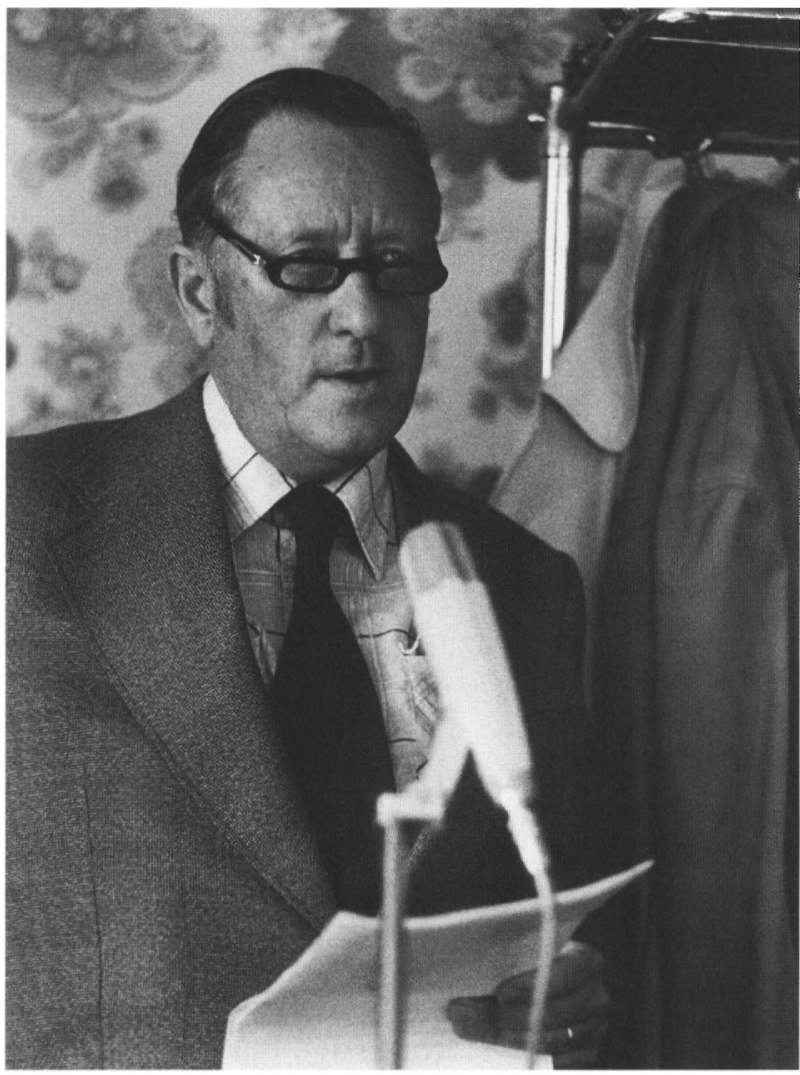

H. V. Gregersen holder foredrag $i$ Glückstadt, forud for Historisk Samfunds byvandring ved den store egnsvandring $i$ september 1978. Foto $i$ Institut for sønderjysk lokalhistorie.

At Anglerne kom fra det sønderjyske område mellem Olmersdiget og Ejderen blev betvivlet af Anders Bjerrum, eftersom han ikke kunne finde belæg herfor $i$ form af nordiske sproglevn efter deres indvandring til Britannien. Han mente derfor, at Anglerne ikke kunne være kommet fra Sønderjylland, hvorfra der kun kendes nordiske sprogminder.

Jeg hævder heroverfor, at for det første udvandrer et helt folk ikke. Ligesom Beda også nævner Jyderne i Britannien, ved alle jo, at de også fortsat lever i Jylland. Det samme gjaldt Anglerne. Hovedparten af dem blev i deres hjemstavn, og ligesom man ved hjælp af dialekten ved, hvor Jyderne har deres bostavn, gælder det samme om Anglerne. Deres lidt syngende dialekt (»den musikalske akcent«) findes overalt i området syd for Olmersdiget, i Sundeved og på Als, men er gået tabt syd for vor landegrænse som følge af Sydslesvigs fortyskning. 
Britannien var $i$ hovedsagen blevet overtaget af Sachserne, efter at Romerne havde forladt øen. Sachserne udgjorde hovedmassen af den nye befolkning. Da de to nordiske folk, Anglerne og Jyderne, også kom derover, udgjorde de et mindretal i forhold til Sachserne, og når de ikke har efterladt sig sproglevn fra tiden efter deres indvandring, skyldes det simpelthen, at de hurtigt har tilegnet sig Sachsernes vestgermanske (»oldplattyske«) sprog. En parallel har vi i den hurtighed, hvormed indvandrere til Nordamerika fra Tyskland og Skandinavien har overtaget flertalsbefolkningens engelske sprog.

Jeg har selv et par børnebørn, der efter tre måneders ophold i USA i deres amerikanske folkeskoleklasse kunne følge med i alt, hvad der foregik, ja ovenikøbet i deres hjem talte engelsk indbyrdes, når de mente sig uhørte af forældrene! Så hurtigt går det med et sprogskifte til et beslægtet sprog, og der er derfor ingen grund til at følge Anders Bjerrum i hans opfattelse af, at Anglerne i England måtte have været et vestgermansk talende folk, indvandret fra fjerne tyske egne.

Men hvorfor blev Anglerne verdenskendte og gav navn til England? Det hænger sammen med deres folkenavns lighed med det latinske navn for himmelens engle! "Anglii“ er Anglerne, mens "angli« er englene. Sachserne i Britannien og efter indvandringen også Anglerne og Jyderne blev kristne, alt imens Sachsernes hovedfolk i det nordvestlige Tyskland var hedninger og kæmpede en forbitret kamp mod de kristne Frankere, der ønskede at indlemme deres land i Karl den Stores vældige rige. Under disse forhold kunne Sachserne i Britannien befrygte, at også de kunne blive angrebet. Sachserkongen Offa forhandlede derfor med Karl den Store under titel af "Rex Anglorum", ligesom Beda kaldte sin bog "Angler-folkets kirkehistorie«. Både stat og kirke fremhævede således Angler-navnet på bekostning af deres sachsiske herkomst. Wessex, Essex og Sussex vidner endnu om dem, men fællesnavnet for det samlede rige blev »Anglia«, og først efterhånden vandt kunstnavnet "Anglo-Saxon « frem.

At Anglerne fra det sønderjyske område blev verdenskendte som navngivere til England og englændere er i sandhed et af historiens luner.

\section{NOTER}

1. Træk af den slesvigske salthandels historie (SM 1947, s. 85-92); Den Lüneburgske Saltoktroi. Bidrag til salthan- delens historie $\mathrm{i}$ hertugdømmet Slesvig (1962, 284 s.); Den Lüneburgske Saltoktroi (SÅrb 1964, s. 509); Nord- 
europas forsyning med salt $\mathrm{i}$ ældre tid (Kulturgeografi 1972, s. 265-288 (i samarbejde med A. Krarup Mogensen)); Salt (Dansk Kulturhistorisk Opslagsværk, I-II, 1991, s. 755-757); Salthungeren som drivkraften i vore ældste udenrigskontakter (SM 1996, s. 193-199).

2. Hvor afholdtes Urnehoved landsting? (Hejmdal 1948 5/5); Hvorfor Umetinget ikke er blevet afholdt på Logpold (Jydske Tidende 1948 17/6); Løgpold og landstinget på Urnehoved (Hejmdal 1948 19/8); Stenbjerg kro (SM 1948, s. 137-139); Landstinget på Urnehoved (SM 1949, s. 17-28); Urnetinget - et genmæle (SM 1949 s. 164); Landstinget på Urnehoved. Et afsluttende svar (Hejmdal 1949 8/1); Urnehoved landsting. Endnu et afsluttende svar (Hejmdal 1949 3/3); Oldtidens og tidlig middelalders Hærvej uden om Urnehoved (Nordslesvigske Museer, 6, 1979, s. 79-84); Kirkeeje i Bjolderup sogn i 1443 (SÅrb 1951, s. 155-159).

3. Bjolderup Sogns Historie, 1951-1956, s. 7-57: Fra de ældste tider; Landstinget på Urnehoved, Sogn og fogderi; Sognet i ufredstider, s. 75-80; Kirkens og præsternes økonomiske forhold; s. 209-229: Frigårdene; De nationale forhold indtil 1864, s. 231-252; Sogn og ovrighed; Den folkelige og nationale udvikling under preussisk styre, s. 399-421; Tillæg: Ældre aktstykker i oversættelse. Bolderslev i førkristen tid. Et forsøg på at tolke egnens gudetro i tiden c. 500-c. 1000 (SM 1951, s. 49-55); Ved pastor Ivar Bjerns hustrus død i Bjolderup (SM 1958, s. 147-148); Bjolderup-stenens udsmykning (SÅrb 1967 , s. $319-320$ ); Snafs og Urne samt ottingstallet i Bolderslev (SÅrb 1975, s. 5-20).

4. Sognefogederne i Kær herred i tiden mellem krigene (SM 1949, s. 62-64); Sognefogederne i Skærbæk og Svanstrup fogderier under Treårskrigen (SM 1949, s. 96-98); Et sindelagsskifte for hundrede år siden (SM 1950, s. 1114); Fra den nationale vækkelse i landsognene omkring Aabenraa (SÅrb 1951, 161-201); Af Slogs herreds nationale historie indtil 1864 (SÅrb
1953, s. 92-94); Hjemmetyskheden i Vilstrup sogn for hundrede år siden (SM 1953, s. 57-58); Sognefogeder i Ubjerg mellem de slesvigske krige (SM 1953, s. 62-63); Sognefogeder og sandemænd i Felsted under oprøret (SM 1953, s. 157); Hjemmetysker (SM 1956, s. 155-157, 174); Da møller J.H. Hartz blev arresteret. En episode fra Bevtoft i 1848 (SM 1958, s. 206209); Nationalpolitiske tilstande i Lundtoft herred i 1848 (SM 1959, s. 132-136).

5. Mere om Jürgen Brag (SM 1955, s. 135-138); Et par hjemmetyske røster i anledning af stændervalget i 1860 (SM 1953, s. 45-47); Grænselandsskæbner (spec. Grauer) (SM 1953, s. 92-94); Præstefamilien Grauers skæbne (SM 1963, s. 63-65); Gehejmeråd Jürgensens tyskhed. Et korrektiv til H.P. Hanssen: Et Tilbageblik IV, s. 217 (SM 1949, s. 5-7); Fysikus Dr. A.W. Neuber. Med særligt henblik på hans nationalpolitiske udvikling (SM 1959, s. 210-218, 225-227); Provst Hans Peter Prahl og Haderslev provsti i 1864 (SM 1956, s. 132-138); Thies Hansen Steenholdt. Med et par randnoter til en afhandling i Zeitschrift der Gesellschaft für S-H Geschichte (SM 1956, s. 81-86); En nytårsaften for 100 år siden. Et bidrag til Thies Steenholdts historie (SM 1948, s. 218-220); Herredsfoged August von Wardenburg (SM 1950, s. 142-145).

Asmus Eschelsen fra Nybal. En forkæmper fra nationalitetskampens tidligste år (SM 1955, s. 104-107); Sonderjyden Nis Hanssen "Bondesøn «. Patriot, skolemand og præst (Sprogforeningens Almanak 1955, s. 37-56); Løgn er også en videnskab (Sprogforeningens Almanak 1961, s. 48-52); Sognefoged H. Raffnsøe, Ástorp, Taps sogn og adressen til civilkommissærerne i 1864 (SM 1950, s. 51-56); Den dansksindede pastor Jørgen Michaelsen (SM 1954, s. 157); Hans Peter Niendahl. Et degneliv for hundrede år siden (SM 1951, s. 140-144); Den store adresse til regeringen i 1861 (SM 1967, s. 168-169); Kongetroskab i det gamle Svejrup (SM 1966, s. 199); Burkal sogn 1864 (SM 1950, s. 154-155); Slesvigske 
Skikkelser. Hans Christian Reuter 1804-1872 (Front og Bro, 3. årg., s. 131132); Sognefogedskiftet i Løjt 1867 (SM 1953, s. 158); Provst Jep Hansens brev til C. F. Allen om Hjordkær sogn (SM 1972, s. 80-89).

6. Præsten Joh. Kok og skolevæsenet i Burkal sogn (SÅrb 1954, s. 50-59); Fra Kloster-politikkens dage (SM 1952, s. 75-77); Præsten Holten Lützhøft i Bylderup 1851-1864 (Ribe Stifts Aarbog 1950, s. 52-59; SM 1999, s. 12-18); Moralske tilstande i Slogs herred i midten af det 19. Arrhundrede (SM 1957, s. 94-96); Præsten Lützhøfts fordrivelse fra Bylderup sogn i 1864 (SM 1950, s. 102-112); De kirkelige tilstande i Felsted under pastor Mørk-Hansen (SM 1953, s. 184); Pastor Mühlensteth og "negerkvinden " (SM 1953, s. 172); Herman Bangs fader, Frederik Ludvig Bang, præst i Asserballe (Kirkehistoriske Samlinger, 7. rk., 2. bd., s. 267272; Haderslev Stiftsbog, 1978, s. 6473); Da provst Odin W. Tidemann forlod Tønder (SM 1958, s. 148); Et par breve til herredsfoged Blaunfeldt $i$ Fleckeby (SM 1960, s. 182-185); Valdemar Thisted som senderjysk folkelivsskildrer (SM 1962, s. 258-262; 1963, s. 7-10); Præstefamilien Marckmann i Hoptrup (SM 1967, s. 172-191); Mourits Mork Hansen: Livs-Erindringer, (1968, 346 sider); Johannes Fibigers bevarede dagbogsnotater fra 1856-57 (Haderslev-Samfundets Årsskrift 1973-74, s. 27-44); Nogle dagbogsblade fra sommeren 1850 (SM 1977, s. 101-105).

7. Aabenraa Bys Historie, I, 1961; II, 1967; III, 1974. I, s. 5-66: Middelalderen; I, s. 185-239: Tiden 1660 til 1720; II, s. 130-183: Fra Kielerfreden til Treårskrigen. Aabenraa (Danmark for og nu, Vest- og Sydjylland, 1954, s. 339352; Bidrag til Aabenraas økonomiske historie indtil ca. 1730 (SÅrb 1949, s. 56-91); Omkring Sankt Nikolaj i 1600tallet (Aabenraa Statsskoles Samfunds Årsskrift, 1949, s. 9-11); Aabenraa på Wallensteins tid (Aabenraa Statssk. Smfds. Årsskrift 1952, s. 5659); En smuglerhistorie fra det gamle Aabenraa (SM 1953, s. 105-107); Præstestrid i Aabenraa 1726 (SM
1953, s. 157-158); Nationalistiske udskejelser i Aabenraa 1848 (SM 1953, s. 144); To aabenraaske stjernekiggere fra året 1835 (SM 1958, s. 147); Lidt om den Günderothske Stiftelse i Aabenraa (SM 1958, s. 169-170); Postvæsenet i Aabenraa i ældre tid. I anledning af 200-året for den gamle Postmestergård i Sondergade (SM 1958, s. 217225, 246); En aabenraask magistratsudtalelse fra jødeemancipationens tid (SM 1959, s. 34-36); Prins Christian Frederiks besøg i Aabenraa i 1831 (SM 1959, s. 113); Rådhuset i Aabenraa (SÅrb 1959, s. 132-136); Da man droftede en jernbanelinje fra Aabenraa til Hjerting (SM 1959, s. 178-179); Provst Peter Paulsens Åbenrå-kronik for året 1824 (SM 1961, s. 1-5); Doktor Faust i Åbenrå (SM 1961, s. 81-82); Udrensningen blandt Aabenraas advokater efter Treårskrigen (SM 1962, s. 159-163); Haderslevs, Aabenraas og Senderborgs krav om dansk retssprog efter 1850 (SÅrb 1962, s. 155-166); Om urmagerslægten Green i Aabenraa (SM 1963, s. 197-199); Åbenuả Bys Skrå (SM 1965, s. 176); Frederik Fischer om sit virke (SM 1968, s. 49-52); Nationale og religiøse brydninger i Aabenraa for 1864 (SM 1969, s. 302305); Sønderjyske skippere pă Ishavsfart før år 1700 (SM 1981, s. 24); Da gassen sprang ved Aabenraa (SM 1981, s. 144); De gamle veje mellem Aabenraa og dets opland (SM 1987, 65-70); Aabenraa Bykrønike 1620 med tilføjelser 1635-41 (88 sider, 1987); Aabenraas ældre historie (Aabenraa Statsskoles Samfunds Aarsskrift 1992, s. 19-27), Særtryk.

8. Messe og Marked. Det landskendte Kliplev marked (1955, 120 s.); Messe og Marked. Fra det gamle Kliplev sogn og Søgård gods (1974, $149 \mathrm{~s}$ ); Skt. Hjælper. En randnote til en afhandling i Sønderjyske Årbøger 1986 (SÅrb s. 194-197); Pottemageriet i Kliplev sogn (SM 1954, s. 147-152; Fra Kliplev sogn 1990, s. 3-9); Fra overgangstiden mellem dansk og preussisk styre. Danskhedstilkendegivelser i Kliplev efter 1864 (SM 1955, s. 8185); Det tyske gudstjenestesprog i Kliplev (SM 1955, s. 125-127); Aaben- 
raa-Flensborg chausséen og ødelæggelsen af det gamle Søgård (SM 1959, s. 90-91); Thomashus-Tømmeshus (SM 1980, s. 281-285).

9. Niels Heldvad. Nicolaus Helduaderus. En biografi (1957, 201 s.); Niels Heldvad. Nicolaus Helduaderus. 1564-1634. Ins Deutsche übersetzt von Richard Todsen (1967, 272 s.). Sonderjyden Niels Heldvad. Præst, folkeskribent og historiker (Sprogforeningens Almanak 1952, s. 18-33); Af Niels Heldvads årsoptegnelser 15011623 (SM 1952, s. 54-61); Bonde og øvrighed i Aabenraa amt omkring år 1600 (SÅrb 1955, s. 153-180); Et velment råd før et ægteskabs indgåelse, meddelt af Niels Heldvad (SM 1956, s. 175); Det menneskelige legeme og dyrekredsens tegn. Lidt om den astrologiske medicin $\mathrm{i}$ det 16 . århundrede med særligt henblik på Niels Heldvad (SM 1956, s. 177-185); Helligkilden i Hellevad (SM 1958, s. 147); Johann von Wouwern - en nordeuropæisk humanist på godt og ondt (SÅrb 1960, s. 81-97); Niels Heldvad: En smuk ihukommelse (SÅrb 1960, s. 258-259); Nogle hăndskrevne tilføjelser til Niels Heldvad: Sylva Chronologica (SM 1963, s. 82-86); En fabeloversættelse af Niels Heldvad (Asinus vulgi) (Danske studier 1964, s. 24-31); Helduader(us), Nicolaus (dänisch: Niels Heldvad) (Schleswig-Holsteinisches Biographisches Lexikon, 1979, V; s. 123-125). Christian IV og Sonderjylland (Sprogforeningens Almanak 1953, s. 49-52; SM 1988, s. 100-108).

10. Petrus Generanus (SM 1957, s. 49-61); Hans Jacobsen Skierbek og hans stambog (SM 1975, s. 365-370); Humanister fra Skærbæk præstegård (SM 1951, s. 81-84); Jacob Fabricius den Yngres visitats i Kliplev og Kværs i 1639 (SM 1961, s. 200-204); Provst Kenckel og Tønder provstis præster (SM 1952, s. 187-188); Troels Amkiel (Toldsted ved Hærvejen, 1978, s. 156179); Konfirmationens indførelse - et 300-års minde i sønderjysk kirkehistorie (Haderslev Stiftsbog 1982, s. 38-39); Hans Adolph Brorson som visitator i vestslesvigske sogne (SM 1960 , s. $236-240,257-262 ; 1961$, s. $36-$
38, 82-84, 122-124); Johannes Prætorius (I.) (SM 1982, s. 211-220).

11. Gotiske skriftprover fra senderjyske arkivalier (SM 1959, s. 238-244, 256$260 ; 1960$, s. $11-17,69-72,94-96,117-$ $120,137-140,161-168$, 204-107, 248251); 1961, $70 \mathrm{~s}$.

12. Kobbersted. Et stednavn som historisk kilde (SM 1951, s. 102-103); Stednavnene Årslev, Årtoft og Årsbjerg (SM 1955, s. 37-39); Kirkestuf og sakrale marknavne i Sonderjylland (SÅrb 1956, s. 74-89); Stednavne på Urnehoved (Sprog og Kultur 1956, s. 70-74); Over og Neder Jerstal (SM 1960, s. 188); Fra Trejborgs sidste dage (SM 1961, s. 142152); Det hellige blod til Lysabild (SM 1964, s. 267-270); Slesvig og Holsten: Folkeslag (med kort); Sproglige og kulturelle skel i Slesvig (med kort) (Historisk Atlas. Danmark 1988, s. 244, 245); Om det kontinuerlige i vor historie (Stambladet 1963, s. 243-248); Lagoni, et fremmedklingende navn af hjemlig oprindelse (SM 1960, s. 224); Ahlmann-ålmand? (SM 1960, s. 225, 251); Forordningen om faste familienavne 1771 (Egnen omkring Vojens, 1977, s. 103).

13. Studedriften forbi Toldsted i 1600-tallet (Jyske Samlinger 1948, s. 139-161); Toldsted (SM 1948, I. Under Arnkielerne, s. 162-165; II. Fra Toldopkrævningssted og Kro til Bondegaard, s. 173-177); Toldsted ved Hærvejen. Arnkielernes hjemstavn, Umehovedegnens og oksehandelens historie $(1978,230$ s.). Studedrift og toldopkrævning $i$ middelalderen langs den sønderjyske Hærvej (SÅrb 1973, s. 513); Gammel Ribervej og Toftlund toldsted (SÅrb 1982, s. 31-44); Toldregnskabet fra Haderslev 1539 (Profiler i nordisk Senmiddelalder og Renaissance. Festskrift til Poul Enemark 1983, s. 165-172); Fremmede okseopkøbere i Danmark i 1508 (SÅrb 1984, s. 5-12); Kvæghandel (Dansk Kulturhistorisk Opslagsværk, I-II, s. 510512). Den flensborgske varehandels kår i kriseårene $i$ slutningen af 1730'erne (SÅrb 1958, s. 75-83).

14. Laurids Skaus brevveksling med politiske venner i København (1966, 726 s.); Laurids Skaus brevveksling med 
politiske venner i Sønderjylland (2 halvbind, 1970, $936 \mathrm{~s}$.); Et par breve af A.F. Tscherning til Laurids Skau (SÅrb 1963, s. 72-81); Bonden Laurids Skau 1817-1864 (SM 1964, s. 170-172); K. Sicks inspektionsrejse gennem Sønderjylland i 1845 (SM 1965, s. 300312); Laurids Skau og Goldschmidt. En skildring på grundlag af breve og artikler (SÅrb 1967, s. 110-152); Kampen for Laurids Skaus eftermæle. Et bidrag til den senderjyske historieskrivnings historie (SÅrb 1969, s. 148179); Laurids Skau. Bonde og taler, politiker og embedsmand - det danske sprogs talsmand (Sprogforeningens Almanak 1969); Laurids Skaus efterslægt på Mariegård i Gl. Haderslev (SM 1970, s. 284-298); Laurids Skau og Sydslesvig (SM 1983, s. 136138); Sønderjyden Laurids Skaus Livsroman, 1992, 312 s.; Den nødstedte August Lorenzen (SÅrb 1992, s. 165-170).

15. Plattysk i Sonderiylland. En undersøgelse af fortyskningens historie indtil 1600-årene (1974, 393 s.); Plattdeutsch im Grenzland (Flensburg 700 Jahre Stadt, 1984, s. 69-84); Die Bedeutung der niederdeutschen Kultursprache im geschichtlichen Prozess, der zur Verdeutschung Südschleswigs führte (Niederdeutsch in Skandinavien, II, s. 116-124. Acten des 2. Nordischen Symposions "Niederdeutsch in Skandinavien " in Kopenhagen 18.-20. Mai 1987); optrykt i Die Heimat 1987, s. 209-214; Das Kollegiatkapitel Hadersleben (850 Jahre St. Petri Dom zu Schleswig, Schriften des Vereins für Schleswig-Holsteinische Kirchengeschichte, 1. Reihe, Bd. 33, s. 221-228); Det middelalderlige kollegiatkapitel i Haderslev og dets embedsområde, Barved syssels provsti (SÅrb 1985, s. 15-34).

16. Egnen omkring Vojens. En sønderjysk kommunes historie. Tiden indtil 1864 $(1977,199$ s.); Hytten på gravhøjen ved Vedsted kirke (SM 1960, s. 73-75); Den forfærdelige misvækst i 1819 (SM 1957, s. 103-107); Tørning, Tørninghus, Trrning Ladegård, Trrning Mølle, Torning Kro, Torning Tinghus $(1982,51 \mathrm{~s})$.
17. "Det skæve Sønderiylland" - Hvorfor? (1990. 115 sider); Det slesvigske bispegods på Aabenraa-egnen (SM 1973, s. 393-399); Savsevejen, et æeldgammelt vejstræk (SM 1952, s. 180183); Forsvundne kirker langs med Hærvejen gennem Nordslesvig (SM 1974, s. 237-247); En nyopdaget vejspærring over Savsevejen (SM 1976, s. 8-15); Den senmiddelalderlige ødelægning i Bov sogn (SM 1977, s. 266270); Den store ødelægning i slutningen af middelalderen (Egnen omkring Vojens, 1977, s. 30-40); Senmiddelalderlig ødelægning på det slesvigske domkapitelgods. Nogle overvejelser omkring oplysningerne i jordebogsmaterialet (Kongemagt og Samfund i Middelalderen. Festskrift til Erik Ulsig, 1988, s. 337-345); Adelsgods og stiftsgods (Løjt Sogns $\mathrm{Hi}$ storie, 1988, s. 29-34). Om reciprokke stednavne $i$ det sønderjyske (Plov og Pen. Festskrift til Svend Gissel 4.jan. 1991, s. 25-32); Krisen i 1300-tallet (SM 2000, s. 44-45).

18. Breve fra J.P. Junggreen (SÅrb 1964, s. 385-392); Breve fra J.P. Junggreen (SÅrb 1969, s. 11-24); Tre breve fra Köller-tiden af Rasmus Clausen (SM 1964, s. 1-6); Sonderjyske præster under "Statsræesonens" vilkår (Haderslev Stiftsbog 1970, s. 17-25); H.P. Hanssen og sindelagsgræensen. Et brev fra Rasmus Clausen, Smedager, til Peder Skau, Bukshave (SM 1983, s. 233-239); Detlef Peter Wilhelm Theodor Tiedje - lærersønnen fra Eidersted, der til sidst var præst i Øsby ved Haderslev (SM 1963, s. 206-208); Fra ophævelsen af Prag-fredens artikel V til Hans Krügers ded (Festskrift til Johan Hvidtfeldt, 1978, s. 85-103); Replik. Om Hans Krüger (Tidehverv april 1989); Frederik Fischer om sit virke (SM 1968, s. 49-52); Da Gustav Johannsen i 1886 kåredes til rigsdagskandidat (SM 1984, s. 300-303). Christian IXs buste i sønderiyske hjem (SM 1969, s. 86-89).

19. Danmarks Historie. Slesvig og Holsten før 1830 (487 s., 1981).

20. Den nationalpolitiske udvikling i grænseegnene $\mathrm{i}$ historisk belysning (SM 1966, s. 381-386); Flensborg og 
Tønder - og selvbestemmelsesretten! (SM 1971, s. 446); Sprogligt-kulturelle skel i Sønderjylland belyst ved en familietradition $\mathbf{i}$ en opbyggelsesbog (SM 1975, 37-39); Flensborgeren Meinekes testamente fra 1332 (SM 1985, s. 150-151); Om baggrunden for Sydslesvigs fortyskning og for hjemmetyskheden i Nordslesvig (SM 1985, s. 175-182); Schleswig-Holstein als geschichtlicher Begriff (Grenzfriedenshefte, 1985, s. 69-73); Var Skt. Nikolai i Aabenraa en tysk kabmandskirke? (SM 1986, s. 112-121); Nogle betragtninger over den historiske baggrund for hjemmetyskheden i Nordslesvig specielt med henblik på Tønder og Højer (SÅrb 1986, s. 5-35); Die soziologische Struktur der Bevölkerung Nordschleswigs in ihrer Bedeutung für die national-politische Entscheidung (Grenzfriedenshefte 2, 1954).

21. Trap Danmark, Femte Udgave (Haderslev Amt, 1965, s. 101-108, 112, $114,116,131-133) ; 100$ års læreruddannelse ved seminariet $i$ Haderslev (Haderslev Statsseminarium 1884 1984, s. 6-19); Slesvig stifts historie til 1850 (Dansk Præste- og Sognehistorie, X, Haderslev Stift, 1977, s. 9-18, 93-98); En Haderslev-krønike fra 1615. Organisten Claus Møllers skrift om kronologien med tillæg om byens historie (Haderslev-Samfundets Årsskrift 1988, s. 17-30); Haderslev Stift i middelalderen (Haderslev Stiftsbog 1973 , s. 12-26); Den gamle Latinskole - Haderslev Domsogns menighedshus (Haderslev Stiftsbog 1975, s. 6066); Haderslev Domkirkes altersølv fra 1658 (Haderslev Stiftsbog 1968, s. 71-72); Stiftsbyen Haderslev i Sonderjyllands ældre kirkehistorie (Haderslev Stiftsbog 1992, s. 9-26. Også uddelt som gratis særtryk); Hertug Hans Kirke, Hospitalskirken (anonym turistfolder); Vor Frue Kirke Haderslev Domkirke (turistbrochure s.m. Olav Lindegaard; trykt i flere oplag, også på tysk og engelsk).

22. Haderslev stift i middelalderen (Haderslev Stiftsbog 1973, s. 13-26); Plattysk i Sønderjylland (1974, s. 81-
91, 150-163, 220-240, 249-307, 317-333, 343-351); Slesvig stifts historie til 1850, Haderslev domkirkes bygningshistorie, Domsognets præstehistorie til 1851 (Dansk Præste- og sognehistorie, bd. X: Haderslev stift, hefte $1 \& 2$, 1977, s. 9-18, 93-98); Plattdeutsch im Grenzland (Flensburg 700 Jahre Stadt - eine Festschrift 1984, s. 69-84, spec. s. 70, 73-77). Das Kollegiatkapitel Hadersleben. 850 Jahre St. PetriDom zu Schleswig (Schriften des Vereins für Schleswig-Holsteinische Kirchengeschichte, 1 . R., bd. 33, 1984, s. 221-228); Det middelalderlige kollegiatkapitel i Haderslev og dets embedsområde, Barved syssels provsti (Senderjyske Årbøger 1985, s. 15-34). Reformationen i Sonderjylland (1986, 260 s.); Die Reformation im Herzogtum Schleswig (Beiträge zur Husumer Stadtgeschichte, Heft 3/4, 1991, s. 83-90); Reformationen i hertugdømmet Slesvig (SM 2000, s. 159-166).

23. Middelalderens Årup i Ensted sogn (SM 1959, s. 188-192); Gettorf og Årup som valfartssteder (SM 1965, s. 226227); "Sancta Anna udi Obenraa " (SM 1978, s. 239-240); Middelalderen, 15/ 1600-årene (Ensted Sogns Historie, 1987, s. 25-73); Lejt sogn i 14- og 1500årene; Lejttavlen. Et sønderjysk alterskab, s. 31-34); Middelalderen. 1500/ 1600-årene (Løjt Sogns Historie, 1988, s. 22-91).

24. Vikingetiden (H.V. Gregersen: Slesvig og Holsten før 1830, 1981, s. 36-56); Det begyndte for Lindisfarne (Festskrift til Troels Fink, 1982, s. 29-51); Den danske kongemagt ved vikingetidens begyndelse (SẢrb 1983, s. 521); Slesvig/Hedebys og Danevirkes generobring i 983 - et 1000 -års minde (SM 1983, s. 412-413); Kong Godfred og de nordfrisiske ringvolde (SM 1985, s. 74-80, 128).

25. Det begyndte før Lindisfarne (Festskrift til Troels Fink, 1982, spec. s. 3336); Angler-problemet - endnu engang (SẢrb 1989, s. 33-50); Anglemes herkomst; Die Herkunft der Angeln (Slesvigland 1995, s. 24-31, 46-53, 89 95, 116-121). 